\title{
Site U1399'
}

\author{
Expedition 340 Scientists $^{2}$
}

\section{Chapter contents}

Background and objectives. ......... 1

Operations................... 1

Lithostratigraphy............... 3

Paleontology and biostratigraphy .......4

Geochemistry .................6 6

Physical properties .............6 6

Paleomagnetism .............. 8

Downhole logging ...............9

References................. 12

Figures.................. 13

Tables.......................... 36

\section{Background and objectives}

Integrated Ocean Drilling Program (IODP) Site U1399 (proposed Site CARI-08B; $14^{\circ} 23.24^{\prime} \mathrm{N}, 61^{\circ} 42.69^{\prime} \mathrm{W} ; 2900$ meters below sea level [mbsl]) is located west of Martinique (Fig. F1). The objective for Site U1399 was to characterize the processes accompanying debris avalanche emplacement and associated erosion. The seismic and bathymetric surveys for Site U1399 revealed that this site is located on one of the main chaotic deposits and that coring at this site could retrieve volcanic and biogenic sediment with intercalated, large, chaotic unit (interpreted as debris avalanche Deposit 1) (Le Friant et al., 2003; Boudon et al., 2007). In detail, we hope to characterize and quantify the erosional processes of the upper sedimentary layers deposited in the Grenada Basin associated with such mass transport processes and their subsequent incorporation into the flow. Finally, we will compare the characteristics of the deposits from Dominica and Martinique to constrain possible differences in erosional capability and mobility. Sediment above Deposit 1 will be used to better constrain the age of the masswasting event.

\section{Operations Transit to Site U1399}

After a leisurely $1.5 \mathrm{kt}$ move over $12 \mathrm{nmi}$, the vessel stabilized over Hole U1399A with the drill string already deployed to 2800 meters below rig floor (mbrf) at $2215 \mathrm{~h}$ on 28 March 2012. All times reported in this volume are given in ship local time, which was Universal Time Coordinated (UTC) $-4 \mathrm{~h}$. The position reference was a combination of GPS signals and a single acoustic beacon. The positioning beacon was deployed at $2212 \mathrm{~h}$ on 28 March. At the end of operations at Site U1399, the beacon was sent an acoustic command to release. The beacon was retrieved at $0740 \mathrm{~h}$ on 3 April. The vessel was underway at $1430 \mathrm{~h}$ on 4 April to the next site.

\section{Site U1399}

Site U1399 consists of three holes (Table T1). The original plan called for two holes to be cored to 290 meters below seafloor (mbsf). The first hole was successfully cored and was terminated at a total depth of 274.7 mbsf. The second hole was piston cored to a depth of $183.0 \mathrm{mbsf}$ and abandoned when the hole became too unstable to continue coring operations. A dedicated logging hole was then drilled to $240 \mathrm{mbsf}$ to undertake a logging program
1'Expedition 340 Scientists, 2013. Site U1399. In Le Friant, A., Ishizuka, O., Stroncik, N.A., and the Expedition 340 Scientists, Proc. IODP, 340: Tokyo (Integrated Ocean Drilling Program Management International, Inc.).

doi:10.2204/iodp.proc.340.109.2013

'Expedition 340 Scientists' addresses. 
including the triple combination (triple combo), Versatile Seismic Imager (VSI), and Formation MicroScanner (FMS)-sonic tools strings. At the conclusion of logging in Hole U1399C, the drill string was pulled back and, with 40 stands of drill pipe to go at $0930 \mathrm{~h}$ on 3 April 2012, polypropylene rope was found wrapped around the drill pipe. After clearing the drill string of miles of poly line, $28.25 \mathrm{~h}$ later at $1415 \mathrm{~h}$ on 4 April the bottom-hole assembly (BHA) was finally secured on the rig floor. After the rig floor was secured at $1415 \mathrm{~h}$, ending Hole U1399C, the remaining thrusters were pulled and the vessel proceeded underway to the next site. The advanced piston corer (APC) was deployed 55 times. The interval cored with the APC was $388.0 \mathrm{~m}$ with a recovery of $393.49 \mathrm{~m}$ of core $(101 \%)$. The extended core barrel (XCB) was deployed seven times. The interval cored with the XCB was $67.2 \mathrm{~m}$ with a recovery of only $9.43 \mathrm{~m}$ of core $(14 \%)$. Overall recovery for Site U1399 was $89 \%$. Total time spent on Site U1399 was $160.00 \mathrm{~h}$.

\section{Hole U1399A}

With the drill string already deployed to $2800 \mathrm{mbrf}$, the knobbies that had been installed for the dynamic positioning move were removed from the drill string. The drill string was then tripped to just above the seafloor. The precision depth recorder (PDR) was then used to approximate the distance below the rig floor, and the top drive was picked up and spaced out to 2908 mbrf. Hole U1399A was spudded at $0145 \mathrm{~h}$ on 29 March 2012. The seafloor depth was calculated from the length of the first core $(5.1 \mathrm{~m})$ to be 2912.4 mbrf $(2900.8 \mathrm{mbsl})$. The APC was advanced throughout the day and into the following day. APC coring was terminated at $207.5 \mathrm{mbsf}$ on Core 340-U1399A-29H. Core orientation was performed with nonmagnetic core barrels used through Core $12 \mathrm{H}$. Advanced piston corer temperature tool (APCT-3) measurements were taken on Cores 3H through $6 \mathrm{H}$. APC coring was difficult over the entire $207.5 \mathrm{~m}$ interval. Sixteen partial strokes were recorded, and three cores had to be drilled over to release them from the formation. The hole was advanced by recovery. After reaching refusal with the APC on Core $29 \mathrm{H}$, the XCB was deployed, and XCB coring continued to 274.7 mbsf. Coring was terminated after Core $36 \mathrm{X}$. Twenty-nine piston cores were taken over a $207.5 \mathrm{~m}$ interval with a total recovery of $210.45 \mathrm{~m}$ of core $(101 \%)$. Seven XCB cores were taken over a $67.2 \mathrm{~m}$ interval. Only $9.43 \mathrm{~m}$ were recovered (14\%), and the hole was terminated at 274.7 mbsf. Overall core recovery for Hole U1399A was 80\%. The drill string was pulled clear of the seafloor at $2115 \mathrm{~h}$ on 30 March, ending Hole U1399A. Total time spent on Hole U1399A was $47.00 \mathrm{~h}$.

\section{Hole U1399B}

The vessel was offset $\sim 350 \mathrm{~m}$ northeast of Hole U1399A on a line of $050^{\circ}$ while maintaining position with the acoustic beacon deployed at Hole U1399A. Because of the fairly large offset from Hole U1399A, a new PDR depth was recorded for Hole U1399B. Using the new PDR depth, the top drive was picked up and spaced out to 2908 mbrf. Hole U1399B was spudded at $2315 \mathrm{~h}$ on 30 March 2012. The seafloor depth was calculated from the length of the first core to be $2911.8 \mathrm{mbrf}(2900.2 \mathrm{mbsl})$. Orientation was performed and nonmagnetic core barrels were used up to and including Core 340-U1399B-14H. APCT-3 measurements were taken on Cores $3 \mathrm{H}, 6 \mathrm{H}$, and $9 \mathrm{H}$. Similar to Hole U1399A, most of the piston cores were partial strokes and the hole was advanced by recovery. Hole problems were encountered after Core $27 \mathrm{H}$ while running in and trying to land a core barrel. After the drill string was freed, the bit was pulled back a single joint of pipe at a time until rotation and torque could be reestablished. While drilling back to the bottom of Hole U1399B, fill was encountered $15 \mathrm{~m}$ off the total depth. After trying unsuccessfully for $>4 \mathrm{~h}$ to reestablish coring, a decision was made to abandon Hole U1399B. Coring was terminated after Core $27 \mathrm{H}$. Twenty-six piston cores were taken over a $180.5 \mathrm{~m}$ interval with a total recovery of $183.04 \mathrm{~m}$ of core. Overall core recovery for Hole U1399B was $101 \%$. There was one drilled interval of $2.5 \mathrm{~m}$. Final depth for Hole U1399B was 183.0 mbsf. The drill string was then pulled back, and the bit cleared the seafloor at $0900 \mathrm{~h}$ on 1 April, ending Hole U1399B. After pulling clear of the seafloor, the vessel was repositioned $50 \mathrm{~m}$ from Hole U1399A at a direction of $050^{\circ}$. Total time spent on Hole U1399B was $35.75 \mathrm{~h}$.

\section{Hole U1399C}

After discussions with science and operations staff, a decision was made to drill a dedicated logging hole. The vessel was repositioned $50 \mathrm{~m}$ from Hole U1399A at a direction of $050^{\circ}$. After spacing out and dropping an XCB core barrel, Hole U1399C was spudded at $1115 \mathrm{~h}$ on 1 April 2012. An offset depth from Hole U1399A was used for official water depth. Water depth for Hole U1399C was recorded as $2912.4 \mathrm{mbrf}$ (2900.2 mbsl). Drilling continued to $240 \mathrm{mbsf}$, and the hole was completed at $0045 \mathrm{~h}$ on 2 April. After drilling was completed, a $35 \mathrm{bbl}$ sweep was pumped and the XCB core barrel was recovered. The XCB core barrel was found to be twisted off a couple of meters from the cutting shoe. Circulation confirmed that the errant section of core barrel was not still in the bit but had fallen to the bottom of Hole U1399C. The hole was then displaced with $104 \mathrm{bbl}$ of $10.5 \mathrm{ppg}$ mud. The drill string was pulled back to 80.76 mbsf with knobbies installed and hung from the blocks. 
Because of numerous indications of poor drilling conditions, a modified triple combo tool string (without any radioactive sources) was made up and run to bottom. Bottom was tagged at $234.6 \mathrm{mbsf}$. Two passes were made, and the triple combo tool string was then pulled from the hole and rigged down. Next the VSI tool string was rigged up and began running in the hole at $1200 \mathrm{~h}$ on 2 April. The required protective species watch was started, and, following VSI protocols, the seismic guns were soft started and the experiment was begun. The VSI tool string was run to $231.6 \mathrm{mbsf}$, and the VSP experiment continued from the bottom of the hole to the just below the end of pipe. The VSI tool string was then pulled to surface and rigged down at $1930 \mathrm{~h}$. The FMS-sonic tool string was then rigged up and run in the hole to $207.6 \mathrm{mbsf}$ for two passes before being pulled from the hole. After having a little trouble reentering the pipe, the tools were at the surface and rigged down at $0600 \mathrm{~h}$ on 3 April. The drill string was pulled back, and with 40 stands of drill pipe to go at $0930 \mathrm{~h}$ on 3 April, polypropylene rope was found wrapped around the drill pipe. The rest of the day was spent removing miles of polypropylene rope from the drill string as the pipe was slowly pulled from the hole. At $1415 \mathrm{~h}$ on 4 April, the BHA was finally secured on the rig floor. The debris wrapped around the drill pipe included miles of several different types of polypropylene rope, eyes, shackles, swivels, tarps, temporary fencing and other gear. The best guess is that we managed to spool up an uncharted Fish Aggregating Device. When the end of the BHA cleared the rig floor, it was immediately apparent that at some point during the coring/ drilling process at Site U1399 we lost the bit. It is pure speculation whether this happened at the end of Hole U1399B or during the drilling process in Hole U1399C. It is very possible that Hole U1399C was drilled without a bit on the end of the BHA. This would explain the relatively slow penetration rates experienced in certain sections of the hole. After the rig floor was secured at $1415 \mathrm{~h}$ on 4 April, ending Hole U1399C and Site U1399, the remaining thrusters were pulled and the vessel proceeded underway to the next site in cruise mode.

\section{Lithostratigraphy}

Site U1399 is composed of two holes: Hole U1399A was drilled to $270 \mathrm{mbsf}$, and Hole U1399B was drilled to 182 mbsf. Good correlations between the two holes can be established to 182 mbsf.

The lithostratigraphy of Site U1399 consists of eight units $(\mathrm{A}-\mathrm{H})$. The cores are dominated by a combination of hemipelagic mud with interbedded tephra layers, volcaniclastic turbidites, and various types of deformed sedimentary intervals that occur at different depths. Each lithology is described in detail in "Lithostratigraphy" in the "Site U1394" chapter (Expedition 340 Scientists, 2013b).

\section{Unit A}

Depths: Hole U1399A = 0-24 mbsf, Hole U1399B = 0-12 mbsf

Unit A extends from 0 to 24 mbsf in Hole U1399A and from 0 to 12 mbsf in Hole U1399B. The top of Unit A is composed of $30 \mathrm{~cm}$ of oxidized brown hemipelagic mud with high water content. Below this mud, the main part of the unit is composed of hemipelagic mud with abundant interbedded tephra layers. Several thin turbidites are interbedded in the hemipelagic mud in Hole U1399A, whereas only one turbidite is identified in Hole U1399B. Most of the tephra layers and turbidites contain pumice, with proportions of pumice that vary from $5 \%$ to $65 \%$.

\section{Unit B}

Depths: Hole U1399A $=24-50.5$ mbsf, Hole $\mathrm{U} 1399 \mathrm{~B}=12-29 \mathrm{mbsf}$

Unit B extends from 24 to 50.5 mbsf in Hole U1399A and from 12 to 29 mbsf in Hole U1399B. Unit B is composed of a thick sequence of more or less deformed hemipelagic sediment intervals with several areas of inclined and convoluted banding. The unit also contains debris flow deposits (debrites) with a muddy sand matrix. Dispersed lava clasts and deformed tephra layers are often found in the debrite intervals. In some parts of the debrites, mud clasts and pumice clasts are included in the muddy sediment. In Hole U1399A, two intervals of deformed sediment are observed: the first is a $18 \mathrm{~m}$ thick sequence between 24 and $41.5 \mathrm{mbsf}$, and the second is $1.50 \mathrm{~m}$ thick and occurs between 49 and 50.5 mbsf. In Hole U1399B there are also two sequences of deformed mud and associated debrites occurring between 13 and $15 \mathrm{mbsf}$ and 19 and $29 \mathrm{mbsf}$. An interval of $4-4.5 \mathrm{~m}$ of hemipelagic mud separates these two deformed zones.

\section{Unit C}

Depths: Hole U1399A $=50.5-72$ mbsf, Hole $\mathrm{U} 1399 \mathrm{~B}=29-53 \mathrm{mbsf}$

Unit C extends from 50.5 to 72 mbsf in Hole U1399A and from 29 to 53 mbsf in Hole U1399B. Unit $C$ is made of hemipelagic mud with abundant tephra layers and thin turbidites $(<1 \mathrm{~m}$ thick). In Hole U1399A, a few turbidites contain pumice, but most of the turbidites are rich in crystals and massive lava clasts. In contrast, the proportion of pumiceous turbidites is higher in Hole U1399B, with the proportion of pumice reaching $40 \%$ in some cases. The base 
of Unit C is composed of a $1 \mathrm{~m}$ thick interval of hemipelagic mud overlain by a turbidite. This basal turbidite is $8.2 \mathrm{~m}$ thick in Hole U1399A but only $2.1 \mathrm{~m}$ thick in Hole U1399B.

\section{Unit D}

Depths: Hole U1399A = 72-76 mbsf, Hole U1399B $=53-68.5 \mathrm{mbsf}$

Unit D extends from 72 to 76 mbsf in Hole U1399A and from 53 to 68.5 mbsf in Hole U1399B. The upper part of Unit D is composed of deformed sediment intervals with inclined contacts between zones of different colored mud. These deformed intervals contain contorted volcanic layers and muddy sand debrites with abundant mud and pumice clasts. In Hole U1399B, 25 volcanic layers are identified in a $6 \mathrm{~m}$ thick sequence of deformed sediment. The lower part of the unit is composed of weakly deformed hemipelagic mud with inclined (deformed) green laminae.

\section{Unit E}

Depths: Hole U1399A = 76-112 mbsf, Hole $\mathrm{U} 1399 \mathrm{~B}=68.5-102.7 \mathrm{mbsf}$

Unit E extends from 76 to 112 mbsf in Hole U1399A and from 68.5 to 102.7 mbsf in Hole U1399B. This unit comprises a succession of nondeformed hemipelagic mud in which there are interbedded tephra layers and thin turbidites, deformed hemipelagic mud, debrites, and thick turbidites.

The following succession is observed in Unit $\mathrm{E}$ in Hole U1399A from top to base:

- 76-83.3 mbsf: hemipelagic mud that includes tephra layers and small turbidites.

- 83.3-91.5 mbsf: deformed sediment and muddy sand debrite, rich in pumice and mud clasts.

- 91.5-95 mbsf: pumiceous turbidites.

- 95-96.5 mbsf: muddy sand debrites, rich in pumice and mud clasts.

- 96.5-97.9 mbsf: hemipelagic mud with tephra.

- 97.9-112 mbsf: the base of the unit is composed of two thick pumiceous turbidites.

In Hole U1399B the stratigraphy of Unit E is somewhat different:

- 68.5-71.9 mbsf: a pumiceous turbidite (3.2 m thick).

- 71.9-77 mbsf: hemipelagic mud that includes tephra layers.

- 77-90 mbsf: a series of pumiceous turbidites and a few tephra layers within hemipelagic mud. At the base a thick $(7.8 \mathrm{~m})$ pumiceous turbidite is observed.

- 90-97 mbsf: a succession of muddy sand debrites and hemipelagic mud. The hemipelagic mud intervals may represent large mud clasts in the debrites.
- 97-102.7 mbsf: a thick pumiceous turbidite (5.3 m).

\section{Unit F}

Depths: Hole U1399A $=112-142.5$ mbsf, Hole $\mathrm{U} 1399 \mathrm{~B}=102.7-129 \mathrm{mbsf}$

Unit $\mathrm{F}$ extends from 114 to 142.5 mbsf in Hole U1399A and from 102.7 to 129 mbsf in Hole U1399B. This unit is composed of a thick sequence of highly deformed and contorted sediment. It also includes some turbidites and contorted tephra layers, which are observed in both holes. However, the turbidites and tephra layers are thicker in Hole U1399A than in Hole U1399B.

\section{Unit G}

Depths: Hole U1399A = 142.5-191.7 mbsf, Hole $\mathrm{U} 1399 \mathrm{~B}=129-182.3 \mathrm{mbsf}$ (bottom of hole)

Unit $\mathrm{G}$ extends from 142.5 to 191.7 mbsf in Hole U1399A and from 129 to 182.3 mbsf in Hole U1399B. This unit is composed of a thick sequence of pumiceous turbidites, some of which are very $(>5 \mathrm{~m})$ thick. It also comprises a low proportion of interbedded hemipelagic mud with a few tephra layers. Only two intervals of slightly deformed sediment are observed in Unit G: 155-160 and 170.5-178 mbsf in Hole U1399A. These deformed intervals include muddy sand debrites and contorted tephra layers.

\section{Unit H}

Depth: Hole U1399A = 191.7-270 mbsf

Unit $\mathrm{H}$ extends from 191.7 to $270 \mathrm{mbsf}$ and is only observed in Hole U1399A (the depth of Hole U1399B is only $182 \mathrm{mbsf})$. Unit $\mathrm{H}$ is mainly composed of hemipelagic mud with interbedded tephra layers and pumiceous turbidites. The proportion of hemipelagic mud $(70 \%)$ is higher than that found in preceding units, and tephra layers are frequently observed. The proportion of turbidites within the unit is low, and they are generally thinner than those in the preceding units. Pumice is always present in the turbidites, and pumice also occurs in most of the tephra layers.

\section{Paleontology and biostratigraphy}

Core catcher samples from Site U1399 contain calcareous nannofossils and planktonic and benthic foraminifers of varying abundances and at varying levels of preservation. Calcareous nannofossil and planktonic foraminiferal data both indicate ages within the late Pleistocene (Fig. F2), suggesting extremely high sedimentation rates. Reworking of much older (early Pleistocene and late Pliocene) material is 
evident in several samples. Many of the core catcher samples from Site U1399 consist of very coarse grained material containing numerous shallow-water benthic foraminifers and fragments of shell and coral. Well-preserved pteropod and heteropod shells, otoliths, and sponge spicules (Demospongiae) were also found in some hemipelagic samples, notably Sample 340-U1399-3H-CC.

\section{Calcareous nannofossils}

A total of 20 core catcher samples from Hole U1399A and 14 from Hole U1399B were analyzed for nannofossil content; the samples contain an upper Pleistocene species assemblage. Calcareous nannofossils at the top of both holes are generally well preserved and abundant. At the base of both holes, the coarse sediment was unsuitable for nannofossil analysis. Samples 340-U1399A-1H-CC to 17H-CC yielded an abundant upper Pleistocene assemblage of Gephyrocapsa oceanica, Gephyrocapsa parallela, Helicosphaera hyalina, and Emiliania huxleyi. Therefore, these samples were assigned to Zone CN15 (Okada and Bukry, 1980). Early Pleistocene and early Pliocene reworked species were found along with a species assemblage belonging to Zone CN15 with a maximum age of $0.25 \mathrm{Ma}$ (Kameo and Bralower, 2000).

In Samples 340-U1399A-20H-CC to 36X-CC (the base of Hole U1399A), an assemblage similar to the one found at the top of Hole U1399A (Samples 1H-CC to $17 \mathrm{H}-\mathrm{CC}$ ) was found. The presence of Ceratolithus cristatus with the absence of $E$. huxleyi indicates this section should be assigned to Subzone CN14b (Okada and Bukry, 1980). The same group of reworked species was found at the top and near the base of Hole U1399A. Hole U1399B shows a similar upper Pleistocene assemblage with reworked species from the early Pleistocene and Pliocene. C. cristatus is abundant in Sample 340-U1399B-6H-CC (more abundant than in any other sample). In Sample 340-U1399B-17H-CC, an early Paleocene species, Biantholithus sparsus, was found, suggesting multiple sources of the reworked sediments.

\section{Planktonic foraminifers}

Of the 36 core catcher samples from Hole U1399A, 33 were analyzed for planktonic foraminiferal content, along with 25 of the 27 core catcher samples from Hole U1399B. The remaining cores either did not contain any material or contained material too coarse for planktonic foraminiferal analysis. Planktonic foraminifers were present in all samples analyzed, although many of the samples contained extremely low abundances, possibly due to the high volume of volcanic material. In samples with abundant specimens, the assemblage of planktonic foraminifers was diverse but dominated by Globigerinoides ruber (white and pink), Globigerinoides sacculifer, and Neogloboquadrina dutertrei (dextral). Other abundant species include Globorotalia truncatulinoides and Globorotalia tumida. The assemblage does not change significantly throughout Site U1399, and all species present are indicative of warm subtropical waters.

Several datum species were found in both holes; however, reliable datum species were generally not found in samples with low planktonic foraminiferal abundance. Globorotalia flexuosa (0.07-0.40 Ma) and Globigerinella calida (bottom occurrence at $0.22 \mathrm{Ma}$ ) were only found in low numbers. The last occurrences of these datum species are not clearly defined, and no reliable planktonic foraminiferal datum was found at the base of either hole.

Several reworked coarse-grained samples from Holes U1399A and U1399B also contained datum species from the early Pleistocene and late Pliocene. Heavily abraded individuals of Globorotalia tosaensis (top occurrence $[\mathrm{T}]$ at $0.61 \mathrm{Ma}$ ) were found in a number of samples from Hole U1399A and in one sample from Hole U1399B. Specimens of Globorotalia exilis (T $2.10 \mathrm{Ma}$ ) and Globorotalia miocenica (T $2.39 \mathrm{Ma}$ ) were found in Samples 340-U1399A-9H-CC and 28X-CC and 340-U1399B-8H-CC and 9H-CC. Specimens of Dentoglobigerina altispira (T $3.13 \mathrm{Ma}$ ) and Sphaeroidinellopsis seminulina (T $3.16 \mathrm{Ma}$ ) and an abraded possible representative of Globigerinoides mitra (early to late Miocene) were also found in Samples 340-U1399B10H-CC, 340-U1399A-34X-CC, and 340-U1399B$17 \mathrm{H}-\mathrm{CC}$, respectively.

Because these early Pleistocene and older species cooccur with late Pleistocene datum species G. calida and $G$. flexuosa, they cannot indicate the true age of the sediment but instead indicate the age of the sediment found within likely mass-flow deposits.

\section{Benthic foraminifers}

A total of 34 genera and 23 species were identified at Site U1399 in the $>150 \mu \mathrm{m}$ size fraction. Benthic foraminifers examined in Holes U1399A and U1399B varied in abundance, diversity, and preservation (poor to moderate). Hole U1399A has 18 species present, and Hole U1399B has 15. Rotaliids have low diversity and are present in low abundances (1-10 sediments per sample) overall in Holes U1399A and U1399B. Several samples (18) contain noticeable amounts of Amphistegina (1-30 specimens per sample), Cibicides wuellerstorfi (1-10 specimens per sample), and Melonis sp. (1-10 specimens per sample). Amphistegina sp. is common in reef environments ( $\leq 100 \mathrm{~m}$ depth), and their poor preservation within these samples is indicative of reworking consistent with volcaniclastic sedimentation in the area. Miliolids are present, with 
Pyrgo murrhina and Quinqueloculina granulocostata the dominant species in the uppermost six core catcher samples in both Holes U1399A and U1399B. Agglutinated foraminifers are extremely rare, with only Sigmoilopsis sp. present. Benthic foraminiferal abundance was low at Site U1399, ranging between 1 and 49 benthic foraminifers/g of sediment, with the exception of Sample 340-U1399A-4H-CC, which has an abundance of 92 benthic foraminifers/g of sediment.

The lack of dominant species in most samples, as well as the obvious influx of reef material, makes it challenging to provide a paleodepth estimate. However, C. wuellerstorfi is common in middle-lower bathyal to abyssal settings, whereas Pyrgo murrhina is common in middle to lower bathyal areas in the Grenada Basin (Galluzzo et al., 1990). Based on their very similar relative abundances and lack of other abyssal key taxa, a bathyal paleodepth is interpreted for the entire sampled interval.

\section{Geochemistry}

Samples for headspace analyses were taken from 28 depths throughout Hole U1399A. Methane concentrations were only a few parts per million in all but the deepest sample (276 mbsf), which yielded a methane concentration of $690 \mathrm{ppm}$. This sample is slightly deeper than the zone of high methane concentrations observed at Site U1398. Unfortunately, it was not possible to collect any deeper samples from Hole U1399B to confirm the presence of high methane concentrations at this site.

A total of 33 samples were taken for X-ray diffraction (XRD) and carbonate analysis. Overall, XRD patterns are very similar to those obtained from Site U1398. Calcium carbonate concentrations are highly variable and are lower in intervals with higher proportions of volcanic material (Fig. F3A; Table T2). Maximum calcium carbonate concentrations are $\sim 35 \mathrm{wt} \%$, reflecting the greater proportion of terrestrial clay minerals and the absence of significant aragonite preservation. Although there is considerable variation in organic carbon concentrations throughout the interval sampled, they generally decrease with depth. The upper $115 \mathrm{~m}$ of the interval contains several samples with organic carbon concentrations close to $1 \mathrm{wt} \%$, whereas the maximum concentrations observed in the lower $155 \mathrm{~m}$ are $\sim 0.7 \mathrm{wt} \%$ (Fig. F3B).

The pore water profiles illustrated in Figure F4 and listed in Table T3 are close to a classic deep-sea diagenetic sequence in the major ions. Total sulfur concentrations gradually decrease over the same interval in which alkalinity and ammonia show steady increases. The decline in $S$ to $<10 \mathrm{mM}$ occurs at a greater depth than was observed at Site U1398, suggesting that diagenesis-driven oxidation of organic matter is less intense than it was at Site U1398. Calcium concentrations show a decrease with depth suggestive of secondary carbonate precipitation. Magnesium concentrations also decrease with depth, possibly because of uptake during alteration of volcanic material beneath the deepest sample taken from this site. The slight increase in chloride concentrations also reflects uptake of water into secondary mineral phases at depth.

The shapes of the pore water profiles suggests that most of the signal generated by the oxidation of organic carbon is taking place in the upper $60 \mathrm{~m}$ of the sediment column, so the change in organic carbon concentrations between the upper $115 \mathrm{~m}$ and the lower $155 \mathrm{~m}$ of the sediment column may reflect a change in the input of organic carbon to the system rather than changes in preservation. There is, however, a strong caveat to this hypothesis, as the percentage of volcanic material can also vary with depth, and this variation may act to cause variable dilution of a constant input flux of organic carbon to the sediment.

\section{Physical properties}

Magnetic susceptibility generated good correlation between Holes U1399B with U1399A to $180 \mathrm{mbsf}$. Analysis of the correlation suggests no significant differences in lithology between the two holes. Pwave velocities show a significant amount of scatter over short (meter scale) depth intervals but in general increase slightly with depth. Both density and magnetic susceptibility increase where higher concentrations of sand exist in sediment. Shear strength generally increases with depth in both holes, with higher values typically measured with the handheld penetrometer. The measured temperature gradient in the upper $81 \mathrm{~m}$ is $65.4^{\circ} \pm 0.9^{\circ} \mathrm{C} / \mathrm{km}$. There is no evidence in the temperature measurements for either vertical or horizontal fluid flow.

\section{Stratigraphic correlation between Holes U1399B and U1399A}

Good correlation exists between Holes U1399A and U1399B. We used magnetic susceptibility to correlate depths between the two holes (Figs. F5). We trimmed $5.1 \mathrm{~cm}$ off each end of the core sections in the magnetic susceptibility data to minimize edge effects during correlation. Hole U1399A was the reference hole for these correlations because it has the longest continuous record. Both holes have good, continuous recovery down to $\sim 180$ mbsf. Unlike previous sites that had limited core recovery, high core recovery at Site U1399 resulted in clear correlation markers with 
depth. Correlation for the uppermost $20 \mathrm{~m}$ is strong, with only a marginal shift in depth between the holes. At depths below 20 mbsf, however, significant stretching is necessary for Hole U1399B to match observations in Hole U1399A. Despite this stretching, correlation between holes is still very good, suggesting that sedimentary units in each of the holes are similar at these depths but several meters thicker in Hole U1399A. In particular, the 30-60 mbsf interval required significant stretching (in excess of 10-20 m) for the best correlation; however, as Figure F5 demonstrates, a strong correlation exists between sites when we apply this stretching. A similar amount of stretching is also implied from analysis of stratigraphic logs, which further supports the significant offset in correlation picks. Because of this, we were able to pick correlation points to 180 mbsf. Our correlation coefficient using magnetic susceptibility data is 0.66 , with the poorest correlation at 30-60 and 150-180 mbsf, where the most significant stretching of Hole U1399B occurs. Where we make correlations, depth shifts for Hole U1399B are primarily negative (downward) and generally exceed $10 \mathrm{~m}$ at all depths below 20 mbsf. All picked correlation depth shifts are shown in Table T4.

\section{Gamma ray attenuation density, magnetic susceptibility, and $P$-wave velocity}

Magnetic susceptibility shows background values $<1000 \times 10^{-5}$ SI with spikes that are correlated with increased density and the presence of coarse-grained volcaniclastic material. Gamma ray attenuation (GRA) density shows significant scatter in both holes but averages $\sim 1.7 \mathrm{~g} / \mathrm{cm}^{3}$. The significant scatter in GRA density makes it very difficult to recognize a detailed trend; in general, bulk density increases with depth. A sharp drop in GRA density is observed near the base of the proposed slide at 150 mbsf.

Hemipelagic sediment shows high values (>15 cps; maximum $=50 \mathrm{cps}$ ) of natural gamma radiation (NGR) in Holes U1399A and U1399B. In contrast, volcaniclastic sediment has comparatively low ( $<15 \mathrm{cps})$ values. $P$-wave velocity measurements from the Whole-Round Multisensor Logger (WRMSL) show a significant degree of scatter, making it very difficult to ascertain clear velocity trends throughout both holes. $P$-wave velocities vary by $20 \%$ over short (meter scale) intervals. In general, $P$-wave velocity increases slightly with depth (Fig. F6).

\section{Shear strength}

Measurements of undrained shear strength $\left(S_{\mathrm{u}}\right)$ were successfully performed on fine-grained sediment in Holes U1399A and U1399B with the fall cone, auto- mated vane shear (AVS), and handheld penetrometer (Fig. F6). As observed at Site U1398, $S_{\mathrm{u}}$ measurements from the handheld penetrometer are higher than those obtained from the AVS and fall cone, which suggests that $S_{\mathrm{u}}$ measured after core splitting is likely underestimated compared to conditions in the core liner immediately after core recovery.

Another divergence in these measurements is that the fall cone provides lower $S_{\mathrm{u}}$ measurements than the AVS. These differences are mostly found below $60 \mathrm{mbsf}$ in Hole U1399A and below 47 mbsf in Hole U1399B (Fig. F7). This discrepancy is due to the presence of lower remolded shear strength (represented by fall cone measurements) than peak strengths (corresponding to AVS measurements). The ratio between peak and remolded strength, known as sensitivity $\left(S_{\mathrm{t}}\right)$, is $\sim 3$, but it can be $>4$ in both holes (Fig. F8). Therefore, fall cone measurements below 60 mbsf in Hole U1399A and 47 mbsf in Hole U1399B provide a lower bound of shear strength.

$S_{\mathrm{u}}$ measurements performed with the handheld penetrometer and AVS increase downhole in both holes, from $\sim 10 \mathrm{kPa}$ at the top to $\sim 100 \mathrm{kPa}$ at 90 mbsf in Hole U1399A and 75 mbsf in Hole U1399B. Below 60 and 47 mbsf in Holes U1399A and U1399B, respectively, we have fewer measurements because of the increase of coarser materials.

Low values of $S_{\mathrm{u}}$ relative to the trend of $S_{\mathrm{u}}$ increasing with depth are identified in some deformed hemipelagic sediment. The most significant anomaly is found at $140 \mathrm{mbsf}\left(S_{\mathrm{u}}<60 \mathrm{kPa}\right.$, in a highly deformed hemipelagic interval) in Hole U1399A and at $125 \mathrm{mbsf}$ $\left(S_{\mathrm{u}}<60 \mathrm{kPa}\right)$ in Hole U1399B. Other anomalies result from local deformation or the presence of softer hemipelagic intervals, as at 95 mbsf in Hole U1399A $\left(S_{\mathrm{u}}<20 \mathrm{kPa}\right.$ in a mud clast within a debritic matrix, according to core description) and $157 \mathrm{mbsf}\left(S_{\mathrm{u}}<\right.$ $80 \mathrm{kPa}$, undeformed sediment, according to visual core description) in Hole U1399B. The decreases in $S_{\mathrm{u}}$ values at $140 \mathrm{mbsf}$ in Hole U1399A and at $125 \mathrm{mbsf}$ in Hole U1399B may result from a major shear surface (Fig. F7).

No $S_{\mathrm{u}}$ measurements are available between 140 and 150 mbsf in Hole U1399A (the interval is characterized by coarser sediment). At greater depths, $S_{\mathrm{u}}$ measurements were only performed with the fall cone in Hole U1399A (150-185 mbsf) because the sediment was too firm for the handheld penetrometer and AVS to make measurements. The fact that $S_{\mathrm{u}}$ measurements performed by the fall cone are $\sim 50 \mathrm{kPa}$ and do not increase below 150 mbsf, as expected in firm sediment, implies that the sediment is more sensitive than that at more shallow depths. 


\section{$\boldsymbol{P}$-wave velocity}

$P$-wave velocity values measured on the $\mathrm{x}$-axis using the caliper match the $P$-wave logger (PWL) values, which increase downhole. Velocities are correlated with sediment composition: average velocities in hemipelagic mud are generally lower than in volcaniclastic sediment.

\section{Moisture and density}

We collected 60 moisture and density (MAD) measurements (45 from Hole U1399A, including 9 volcaniclastic sand samples, and 15 from Hole U1399B, including 4 clay samples; Fig. F6). The four clay samples match all MAD characteristics of the hemipelagic sediment.

Porosity of 47 hemipelagic sediments ranges between $53 \%$ and $73 \%$. Volcanic sand samples have porosities between $40 \%$ and $50 \%$. However, pumice-rich sand at $179.1 \mathrm{mbsf}$ and finely bedded sand at $267.2 \mathrm{mbsf}$ have porosities of $\sim 60 \%$. As at other sites, the porosity of loose sand may be underestimated as much as $20 \%$ due to draining of pore water during coring, splitting, and MAD sampling. Alternatively, where core recovery, handling, or splitting processes reorganize sand grains, sandy sediment may become undercompacted and yield anomalously high porosities.

Bulk density of hemipelagic samples range between 1.5 and $1.8 \mathrm{~g} / \mathrm{cm}^{3}$. Sandy samples have bulk densities as high as $2.05 \mathrm{~g} / \mathrm{cm}^{3}$. Grain density of hemipelagic samples has a narrow range between 2.5 and $2.8 \mathrm{~g} / \mathrm{cm}^{3}$. The volcanic sand has a grain density similar to that of hemipelagic sediment.

\section{Thermal conductivity}

Thermal conductivity was measured at 103 depths on recovered whole-round sections. Measured thermal conductivity had a mean value of $1.045 \mathrm{~W} /(\mathrm{m} \cdot \mathrm{K})$, with a standard deviation of $0.080 \mathrm{~W} /(\mathrm{m} \cdot \mathrm{K})$ and a standard error on the mean of $0.008 \mathrm{~W} /(\mathrm{m} \cdot \mathrm{K})$.

\section{Downhole temperature}

Temperature was measured with the APCT- 3 at the bottom of Cores 340-U1399A-3H, $4 \mathrm{H}, 5 \mathrm{H}$, and $6 \mathrm{H}$ (24.1, 33.6, 43.1, and $52.6 \mathrm{mbsf}$, respectively) and Cores 340-U1399B-3H, 6H, and 9H (24.7, 53.2, and $81.2 \mathrm{mbsf}$, respectively). Downhole temperature was monitored for 650, 638, 637, 825, 796, 760, and $686 \mathrm{~s}$, respectively. Temperature was calculated from these time series of temperature measurements using TP-Fit (see APCT-3 user manual on the Cumulus/ Techdoc database at iodp.tamu.edu/tasapps/). We assume a thermal conductivity $(\mathrm{k})$ of $1.0 \mathrm{~W} /(\mathrm{m} \cdot \mathrm{K})$ and $\rho \mathrm{C}=3.7 \times 10^{6} \mathrm{~J} / \mathrm{m}^{3} \mathrm{~K}$. To calculate uncertainty, we assume $k$ ranges from 0.9 to $1.1 \mathrm{~W} /(\mathrm{m} \cdot \mathrm{K})$ and $\rho \mathrm{C}$ is between $3.2 \times 10^{6}$ and $4.0 \times 10^{6} \mathrm{~J} / \mathrm{m}^{3} \mathrm{~K}$. At the base of Cores $340-\mathrm{U} 1399 \mathrm{~A}-3 \mathrm{H}, 4 \mathrm{H}, 5 \mathrm{H}$, and $6 \mathrm{H}$ we obtained temperatures of $5.91^{\circ} \pm 0.05^{\circ} \mathrm{C}, 6.56^{\circ} \pm 0.01^{\circ} \mathrm{C}, 7.09^{\circ} \pm$ $0.02^{\circ} \mathrm{C}$, and $7.82^{\circ} \pm 0.04^{\circ} \mathrm{C}$, respectively. At the base of Cores $340-\mathrm{U} 1399 \mathrm{~B}-3 \mathrm{H}, 6 \mathrm{H}$, and $9 \mathrm{H}$ we obtained temperatures of $5.96^{\circ} \pm 0.02^{\circ} \mathrm{C}, 7.72^{\circ} \pm 0.03^{\circ} \mathrm{C}$, and $9.60^{\circ} \pm 0.03^{\circ} \mathrm{C}$, respectively. Uncertainties are similar to the error on the best-fit solution and the probe's measurement accuracy. The temperature of ocean water at the seafloor is $4.25^{\circ} \mathrm{C}$.

A best-fit linear relationship between depth and our eight temperature measurements gives a temperature gradient of $65.4^{\circ} \pm 0.9^{\circ} \mathrm{C} / \mathrm{km}$ (Fig. F9). Using the measured thermal conductivity the implied heat flow is $68 \pm 1 \mathrm{~mW} / \mathrm{m}^{2}$. Bathymetry will not affect the near surface heat flow; however, the high sedimentation rate may reduce the measured heat flow by up to $4 \%$ (Manga et al., 2012). Despite a horizontal separation of $410 \mathrm{~m}$ between Holes U1399A and U1399B, all temperature measurements lie on a single line. This implies that fluid flow is not disturbing the temperature gradient.

\section{Paleomagnetism}

Cores 340-U1399A-1H through $12 \mathrm{H}$ and 340U1399B-1H through $14 \mathrm{H}$ were recovered using nonmagnetic core barrels with the APC. All other APC cores were recovered using standard steel core barrels. The FlexIt core orientation tool was used on all APC cores recovered with nonmagnetic barrels; thus, between 0 and 95 mbsf in Hole U1399A and between 0 and 115 mbsf in Hole U1399B, declination can be corrected to true north. Where FlexIt tool data were not available, declination was guided by discrete inclination (see "Paleomagnetism" in the "Methods" chapter [Expedition 340 Scientists, 2013a]). Expected inclination for the site is $27.2^{\circ}$ during normal polarity and $-27.2^{\circ}$ during reversed polarity, assuming a geocentric axial dipole (GAD). The archive halves of cores from Holes U1399A and U1399B were measured on the three-axis superconducting rock magnetometer (SRM) at $2.5 \mathrm{~cm}$ intervals (Table T5). NRM was measured before $\left(\mathrm{NRM}_{0}\right)$ and after stepwise alternating field demagnetization in a peak field of $20 \mathrm{mT}$ $\left(\mathrm{NRM}_{20}\right)$. Twenty-four discrete samples were collected from the center of the working half of the core for to compare to the SRM data (see "Paleomagnetism" in the "Methods" chapter [Expedition 340 Scientists, 2013a]).

Sediments recovered from Site U1399 are a heterogeneous mixture of hemipelagic sediment and volcaniclastic tephras and turbidites. Below 24 mbsf in Hole U1399A and at 13 mbsf in Hole U1399B, hemipelagic 
sediment is often contorted and deformed (see "Lithostratigraphy"). Sediment deformation in these zones is often severe, and its direction is not constant, making interpretation of paleomagnetic directions related to geomagnetic field behavior difficult. Detailed consultation of the visual core descriptions (VCDs) allowed us to extract intervals less visually affected by deformation and potentially suitable for analysis of geomagnetic field behavior. Figure F10 shows three sets of the same inclination data from Hole U1399A demagnetized at 20 mT: (1) raw inclination (gray) is data from all measured sediment, (2) hemipelagic inclination (blue) is data only from hemipelagic sediment ( $40 \%$ of Hole U1399A data), and (3) nonchaotic inclination (green) is inclination data only from hemipelagic sediment with little visual evidence of deformation ( 20\% of Hole U1399A data). Deformation of hemipelagic sediment is evident in the inclination data; one standard deviation of the hemipelagic inclination is $\sim 42^{\circ}$ in Hole U1399A and $45^{\circ}$ in Hole U1399B compared to $17^{\circ}$ and $16^{\circ}$ for the nonchaotic inclination data from the same core. Greater scatter in paleomagnetic directions coupled with consultation of the core description is the justification for removing these intervals from the data set and restricting interpretation of the behavior of the geomagnetic field to data from nonchaotic intervals. These nonchaotic interval data are presented in Figures F11 and F12.

\section{Results}

$\mathrm{NRM}_{0}$ (red) and $\mathrm{NRM}_{20}$ (blue) intensities are shown for Holes U1399A and U1399B in Figures F10 and F11. $\mathrm{NRM}_{0}$ intensity is moderately high at $\sim 0.1-1 \mathrm{~m} / \mathrm{A}$. $\mathrm{NRM}_{0}$ and $\mathrm{NRM}_{20}$ of material retrieved with standard steel barrels is slightly higher than when nonmagnetic barrels were used, and $\mathrm{NRM}_{20}$ is $<10 \%$ of $\mathrm{NRM}_{0}$. This reflects both the low magnetic coercivity of the sediment and the susceptibility of the material to acquire a strong drill string overprint. This overprint is typically removed by demagnetization at $20 \mathrm{mT}$ when using nonmagnetic barrels, though overprinting of sediment when standard steel barrels are used is a persistent feature in Expedition 340 cores (see "Paleomagnetism" in the "Methods" chapter [Expedition 340 Scientists, 2013a]).

Rifling of the core barrel is evidenced by scattered declination values in all cores recovered with the $\mathrm{XCB}$; thus, inclination is the only reliable indicator of polarity below 207.5 mbsf in Hole U1399A. Biscuiting of sediment makes determination of the degree of deformation difficult, and the recovery of several thick turbidites means that identification of nonchaotic hemipelagic layers is difficult with XCB recovery. Thus interpretation of polarity data recovered from
Site U1399 is restricted to sediment recovered with the APC.

Between 0 and 207.5 mbsf in Hole U1399A and throughout Hole U1399B, SRM and discrete inclination data show scattered but positive values, clustering around the expected GAD inclination (Figs. F10, F11). Declination shows some scatter, but coupled with the positive inclination data this suggests all nonchaotic sediment was deposited under normal polarity conditions. Biostratigraphic ages from planktonic foraminifers and nannofossils suggests the base of both Holes U1399A and U1399B are no older than $400 \mathrm{ka}$ (see "Paleontology and biostratigraphy"). Record continuity is very poor, but paleomagnetic data show no evidence of reversed polarity within the nonchaotic hemipelagic intervals. This conclusion can be used to support the biostratigraphic datums, suggesting that all sediment at Site U1399 was deposited within the Brunhes Chron and younger than 780 ka (Cande and Kent, 1995).

\section{Downhole logging}

After Hole U1399 had to be abandoned, a hole dedicated solely to downhole logging was drilled (see "Operations"). By 0045 h on 2 April 2012, Hole U1399C had been drilled to a final depth of $240 \mathrm{mbsf}$ and the hole was prepared for logging operations. Three tool strings were deployed in the hole over a $25 \mathrm{~h}$ period: the triple combo-Magnetic Susceptibility Sonde (MSS), the VSI, and the FMS-sonic (Fig. F13; see Fig. F11 in the "Methods" chapter [Expedition 340 Scientists, 2013a]). All of these tool strings were slightly modified versions of previous tool strings used during Expedition 340. No radioactive sources were used in this hole as a consequence of unstable hole conditions encountered at Site U1399.

\section{Operations}

Hole U1399C was prepared for logging activities by sweeping with high viscosity mud, pumping a godevil, and displacing with heavy barite-weighted mud. The pipe was pulled to a bit depth of $80.8 \mathrm{mbsf}$, leaving a $\sim 159 \mathrm{~m}$ section of open hole for logging.

The modified triple combo was the same as the triple combo-MSS but without the Hostile Environment Natural Gamma Ray Sonde (HNGS; spectral gamma ray). The HNGS, with the largest diameter of the tools, presents the greatest challenge in passing successfully through the BHA. Because the bottom $\sim 0.5 \mathrm{~m}$ of the last core barrel twisted off into the hole at the end of drilling (see "Operations"), potentially damaging the lockable float valve, it was decided to keep tool string diameter to a minimum by not including the HNGS. The modified triple combo was rigged up 
at $0442 \mathrm{~h}$ and run in the hole to a total depth of $237 \mathrm{mbsf}$ ( $3 \mathrm{~m}$ of infill). Two uplogs were then completed, acquiring magnetic susceptibility, electrical resistivity, gamma ray, and caliper measurements.

The second tool string to be deployed in Hole U1399C was the VSI tool string. Because of the trouble passing the VSI through the BHA in Hole $\mathrm{U} 1394 \mathrm{~B}$, it was decided to add a weight bar to the tool string in Hole U1399C. Preparations for the vertical seismic profile (VSP) experiment commenced with deployment of the air guns to a water depth of $\sim 7 \mathrm{~m}$ off the port side of the R/V JOIDES Resolution. Rig up commenced at $1115 \mathrm{~h}$, shortly followed by the start of the protected species watch at $1130 \mathrm{~h}$. The tools were run in hole at $\sim 1200 \mathrm{~h}$, and a series of uplogs were taken to ensure an accurate depth reference frame, using gamma ray measurements from the triple combo run for comparison. After some delays because of the sighting of a whale within the exclusion zone, the experiment started at $1500 \mathrm{~h}$. Eight stations were taken, with spacing between stations ranging from $\sim 9$ to $27 \mathrm{~m}$.

The final tool string deployment was a modified FMS-sonic tool string. Because good hole conditions were experienced throughout the first two runs, it was decided to run the HNGS with the FMS-sonic in order to add spectral gamma ray to the data set for Hole U1399C. The $\sim 35 \mathrm{~m}$ tool string was lowered into the hole at $2100 \mathrm{~h}$, reaching a total depth of $211 \mathrm{mbsf}$. Because of problems opening the FMS caliper arms during the first pass and rapidly deteriorating hole conditions, three passes of the open hole section were conducted to get a complete FMS data set. Problems were encountered with reentering pipe and passing the tool string through the BHA, meaning that tools did not reach the surface until $0407 \mathrm{~h}$, with rig down complete by $0546 \mathrm{~h}$ on 3 April 2012.

\section{Data processing and quality assessment}

Logging data from Hole U1399C are summarized in Figures F14, F15, F16, and F17. A full data set was achieved from the tool strings deployed with the exception of density data, which is absent because the radioactive source was omitted from the triple combo. As indicated by the HLDS caliper data (Fig. F14), Hole U1399C is relatively in gauge, with a profile similar to Holes U1394B and U1395B. Hole diameter generally increases from $\sim 10$ inches at the base of the hole to 14 inches at the top of the open hole section ( $90 \mathrm{mbsf})$. The exceptions are three washed out zones with hole diameters $>18$ inches that were encountered at 114-115, 129-133, and 137-140 mbsf. FMS caliper data from three subsequent passes suggest that hole conditions deteriorated significantly between the VSI tool string run and the FMS-sonic run. This deterioration is also clear from difficulties encountered in getting the tool string through the open hole section and from periods of increased head tension that suggest that material was falling into the hole or that the hole was closing in during logging operations.

Despite the hole conditions, the repeatability of all of the logging measurements is very good between the multiple passes for both tool strings (Fig. F18). In addition, gamma ray measurements from both tool strings agree well (Fig. F15).

The acquisition of good VSP data relies on coupling of the VSI geophone to the borehole wall, which is best achieved in an in-gauge hole. Hole diameter was sufficiently small in Hole U1399C (Fig. F14) to acquire some good quality data. However, it was clear that maintaining a strong anchoring force over successive shots at any station was challenging, particularly in the shallowest interval between 80 and 140 mbsf. This poor anchoring potential is likely a reflection of the soft formations present and was most evident in the upper four stations. Figure F17 shows the stacked VSP waveforms from the eight stations in Hole U1399C. Corrected one-way traveltimes (green crosses) take into account the geometry of the VSP experiment.

Acoustic velocity data in Hole U1399C are of variable quality, most likely due to the deteriorating hole conditions encountered during the FMS-sonic tool string run. The automatic picking function was not consistently able to identify valid compressional wave $\left(V_{\mathrm{P}}\right)$ values between 80 and $145 \mathrm{mbsf}$. The picking function did a somewhat better job for shear wave velocity $\left(V_{S}\right)$ in this hole, with the exception of an interval between 102 and 112 mbsf. Despite these breaks, there are intervals of good quality $V_{\mathrm{P}}$ and $V_{\mathrm{S}}$ data within the logged portion of the hole, as evidenced by the high coherence regions (red) in Figure F15. Postcruise reprocessing of this data set will improve the data quality, particularly in the problematic zones.

Acquisition of good-quality FMS images requires an in-gauge hole, regular borehole walls, and good tool pad/borehole contact. Despite some problems opening the calipers at the beginning of the FMS-sonic tool string run, the third and final uplog allowed the continuous acquisition of FMS images from Hole U1399C between 88 and 204 mbsf (Fig. F15). Preliminary assessment of the images suggests they are of generally good quality. Data processing includes correction for tool motion, which is effective for vertical shifts of as much as $\sim 1 \mathrm{~m}$. Tool dynamics data from Hole U1399C indicate shifts of $<1 \mathrm{~m}$, with the exception of a few slightly larger shifts between 88 and 105 mbsf. 


\section{Logging stratigraphy}

Downhole logging data are summarized in Figures F14, F15, F16, F17, F18, F19, and F20. The logged interval at Hole U1399C is divided into four logging units primarily on the basis of responses from the tools in the triple combo (gamma ray, resistivity, and magnetic susceptibility). A description of these logging units follows.

\section{Logging Unit 1}

Logging Unit 1 comprises the uppermost $26 \mathrm{~m}$ of the logged interval (80-106 mbsf). This unit is characterized by an overall increase in gamma ray values with depth from $\sim 25$ to $\sim 50$ gAPI. Average gamma ray values in this logging unit are $\sim 33$ gAPI. Magnetic susceptibility and electrical resistivity profiles are similar in character with a small net decrease with depth. True electrical resistivity (RT) in this unit has a mean value of $1.38 \Omega \mathrm{m}$.

\section{Logging Unit 2}

The transition from logging Unit 1 to logging Unit 2, at $106 \mathrm{mbsf}$, is marked by a sharp decrease in gamma ray values that coincides with sharp increases in resistivity and magnetic susceptibility. Similar to logging Unit 1, gamma ray values in logging Unit 2 show a net increase with depth with an average value of $\sim 31$ gAPI. Three intervals have lower gamma ray values (114-115, 129-133, and 137-140 mbsf) and correspond to washed out zones $>18$ inches in diameter (Fig. F14). Between 140 and 150 mbsf there is an interval of increased gamma ray values; this interval is reflected in both the total gamma ray and spectral gamma ray measurements (Figs. F14, F15). Interestingly this increase is not shown in the corresponding natural gamma radiation data from cores recovered in Hole U1399A. Resistivity generally decreases with depth $($ mean $=1.47 \Omega \mathrm{m})$ through this logging unit with localized high-resistivity features (for example, 106-110, 114-116, 126-129, and $\sim 138-140$ mbsf). This trend is repeated in the magnetic susceptibility curve.

\section{Logging Unit 3}

Logging Unit 3 (150-181 mbsf) is characterized by higher amplitude variability in gamma ray values, resistivity, and magnetic susceptibility. Similar to the transition between logging Units 1 and 2, the transition from logging Unit 2 to logging Unit 3 is marked by a stepwise decrease in gamma ray values and increases in resistivity and magnetic susceptibility. Average gamma ray values are lower than in the overlying unit, with a value of $\sim 28$ gAPI, and average resistivity is higher $(1.60 \Omega \mathrm{m})$. Generally lower values of gamma ray coincide with higher values of both resistivity and magnetic susceptibility (Fig. F11). There is no net change in any of the measurements through this logging unit.

The boundary between logging Units 2 and 3 at 150 mbsf coincides with a change in lithostratigraphy from a chaotic unit above to a transition zone below (see "Lithostratigraphy").

\section{Logging Unit 4}

Higher amplitude and more regular variability characterizes logging Unit 4, which extends from $181 \mathrm{mbsf}$ to the bottom of the logged section. More regular gamma ray variations, of $\sim 15$ gAPI, continue through the uppermost $25 \mathrm{~m}$ of this logging unit, after which variations decrease in amplitude. Overall, the mean gamma ray value is $\sim 29$ gAPI. Logging Unit 4 exhibits the most variable magnetic susceptibility profile in Hole U1399C, including some significant peaks, the largest of which (at 205-208 mbsf) corresponds to similarly elevated values of resistivity. This feature with high resistivity and magnetic susceptibility coincides with the depth at which the coring system in Hole U1399A was changed from the APC to the XCB (Fig. F14), suggesting a change in lithology or induration at this depth.

\section{Vertical seismic profile experiment}

One of the expedition objectives is to constrain the seismic stratigraphy of mass transport deposits. The VSP experiment provides a good intermediate step in integrating core and wireline logging data, recorded in depth, with seismic data, recorded in time.

Data acquired during the VSP experiment are summarized in Figures F17 and F19 and Table T6. First arrivals from 31 out of the 123 shots were used in the stack, with the vertical component being the most reliable. Despite several of the shots recorded by the VSI being noisy, eight stations yielded reliable check shot traveltimes ranging from $0.128 \mathrm{~s}$ two-way traveltime at $99.1 \mathrm{mbsf}$ to $0.279 \mathrm{~s}$ at the bottom of the hole (237 mbsf). A comparison of the data from both the VSP and the sonic tool, with predictions of velocity from seismic data at this site (1800-2200 m/s), indicates that measured velocities are slower than predicted (Fig. F19).

\section{Formation MicroScanner images}

Figure F20 shows examples of the FMS images acquired from Hole U1399C. The images indicate a range of textures and features across the logged interval, including a wide range of resistivities. Some surfaces can be identified, ranging from subhorizontal to moderately dipping. Broadly, the images can 
be divided into four sections alternating between conductive (88-104 and 128-149 mbsf) and resistive zones (104-128 and 149-204 mbsf). Two of these boundaries roughly coincide with the logging unit boundaries (Fig. F15) as determined by the triple combo tool measurements. These are the boundaries between logging Units 1 and 2 and logging Units 2 and 3 where there are downhole shifts from more conductive to more resistive tool responses.

Direct comparison between the FMS and core images is not possible because no cores were collected in Hole U1399C. It is clear from all of the sites cored during Expedition 340 that there are often significant differences between two holes at a site, particularly in terms of the thickness of the different formations encountered. Site U1399 is no exception, with offsets in unit boundaries $>10 \mathrm{~m}$ (see "Lithostratigraphy"). For the purposes of core-log integration it is advised to use core data from Hole U1399A, as it lies in closer proximity to logging-dedicated Hole U1399C than Hole U1399B.

\section{References}

Boudon, G., Le Friant, A., Komorowski, J.-C., Deplus, C., and Semet, M.P., 2007. Volcano flank instability in the Lesser Antilles arc: diversity of scale, processes, and temporal recurrence. J. Geophys. Res., [Solid Earth], 112:B08205. doi:10.1029/2006JB004674

Cande, S.C., and Kent, D.V., 1995. Revised calibration of the geomagnetic polarity timescale for the Late Cretaceous and Cenozoic. J. Geophys. Res., [Solid Earth], 100(B4):6093-6095. doi:10.1029/94JB03098

Expedition 340 Scientists, 2013a. Methods. In Le Friant, A., Ishizuka, O., Stroncik, N.A., and the Expedition 340 Scientists, Proc. IODP, 340: Tokyo (Integrated Ocean
Drilling Program Management International, Inc.). doi:10.2204/iodp.proc.340.102.2013

Expedition 340 Scientists, 2013b. Site U1394. In Le Friant, A., Ishizuka, O., Stroncik, N.A., and the Expedition 340 Scientists, Proc. IODP, 340: Tokyo (Integrated Ocean Drilling Program Management International, Inc.). doi:10.2204/iodp.proc.340.104.2013

Galluzzo, J.J., Sen Gupta, B.K., and Pujos, M., 1990. Holocene deep-sea foraminifera of the Grenada Basin. J. Foraminiferal Res., 20(3):195-211. doi:10.2113/gsjfr.20.3.195

Kameo, K., and Bralower, T.J., 2000. Neogene calcareous nannofossil biostratigraphy of Sites 998, 999, and 1000, Caribbean Sea. In Leckie, R.M., Sigurdsson, H., Acton, G.D., and Draper, G. (Eds.), Proc. ODP, Sci. Results, 165: College Station, TX (Ocean Drilling Program), 3-17. doi:10.2973/odp.proc.sr.165.012.2000

Le Friant, A., Boudon, G., Deplus C., and Villemant B., 2003. Large-scale flank collapse events during the activity of Montagne Pelée, Martinique, Lesser Antilles. J. Geophys. Res., [Solid Earth], 108(B1):2055. doi:10.1029/ 2001JB001624

Manga, M., Hornbach, M.J., Le Friant, A., Ishizuka, O., Stroncik, N., Adachi, T., Aljahdali, M., Boudon, G., Breitkreuz, C., Fraass, A., Fujinawa, A., Hatfield, R., Jutzeler, M., Kataoka, K., Lafuerza, S., Maeno, F., Martinez-Colon, M., McCanta, M., Morgan, S., Palmer, M.R., Saito, T., Slagle, A., Stinton, A.J., Subramanyam, K.S.V., Tamura, Y., Talling, P.J., Villemant, B., Wall-Palmer, D., and Wang, F., 2012. Heat flow in the Lesser Antilles island arc and adjacent backarc Grenada Basin. Geochem., Geophys., Geosyst., 13:Q08007. doi:10.1029/2012GC004260

Okada, H., and Bukry, D., 1980. Supplementary modification and introduction of code numbers to the low-latitude coccolith biostratigraphic zonation (Bukry, 1973; 1975). Mar. Micropaleontol., 5:321-325. doi:10.1016/03778398(80)90016-X

Publication: 17 August 2013 MS 340-109 
Figure F1. Site U1399 maps. A. Shaded image of topography-bathymetry and chaotic deposits (interpreted as debris avalanche deposits). $\mathrm{DAD}=$ debris avalanche deposit. (Continued on next page.)

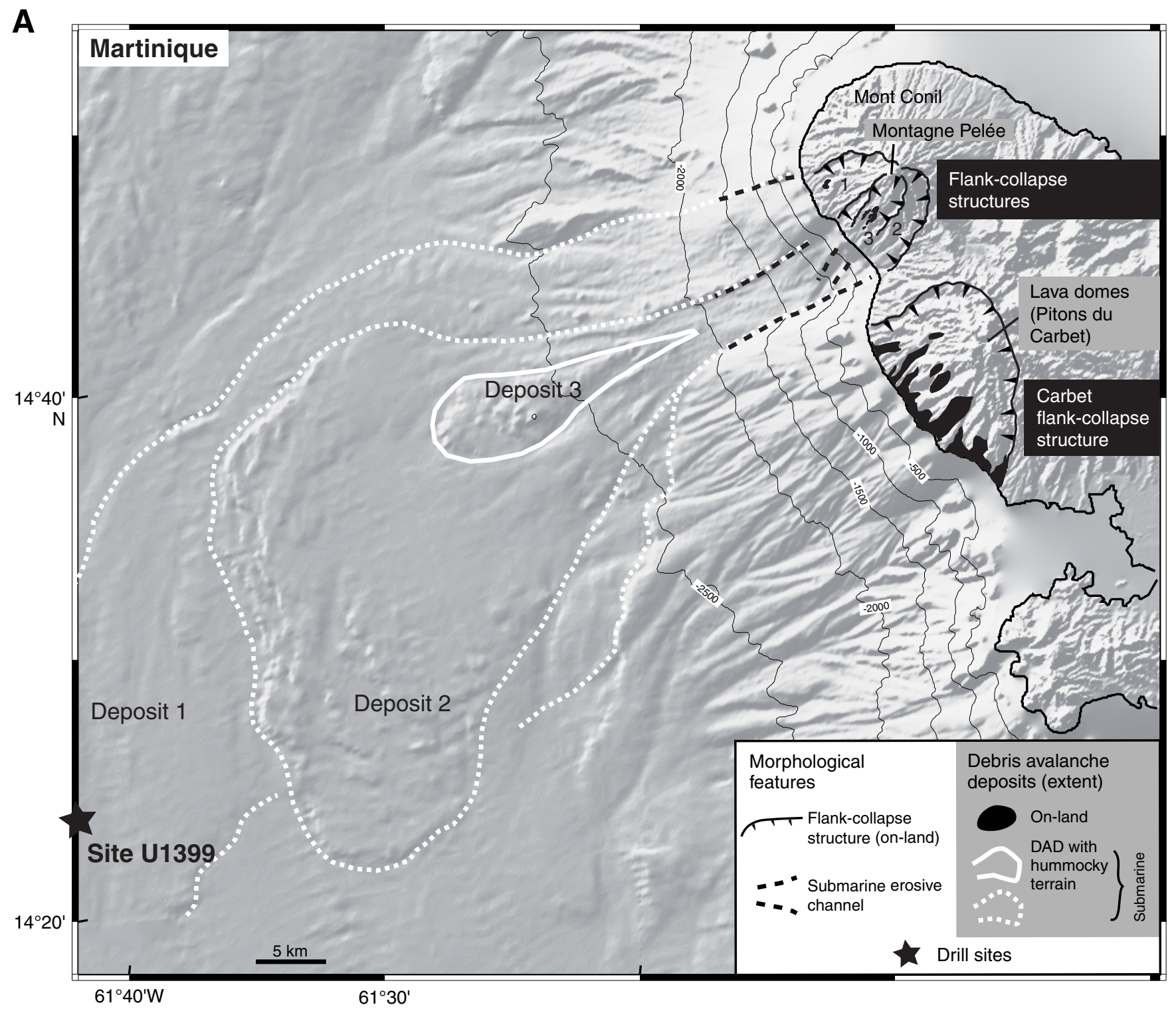


Figure F1 (continued). B. Location of seismic reflection lines across the Site U1399. CDP = common depth point.

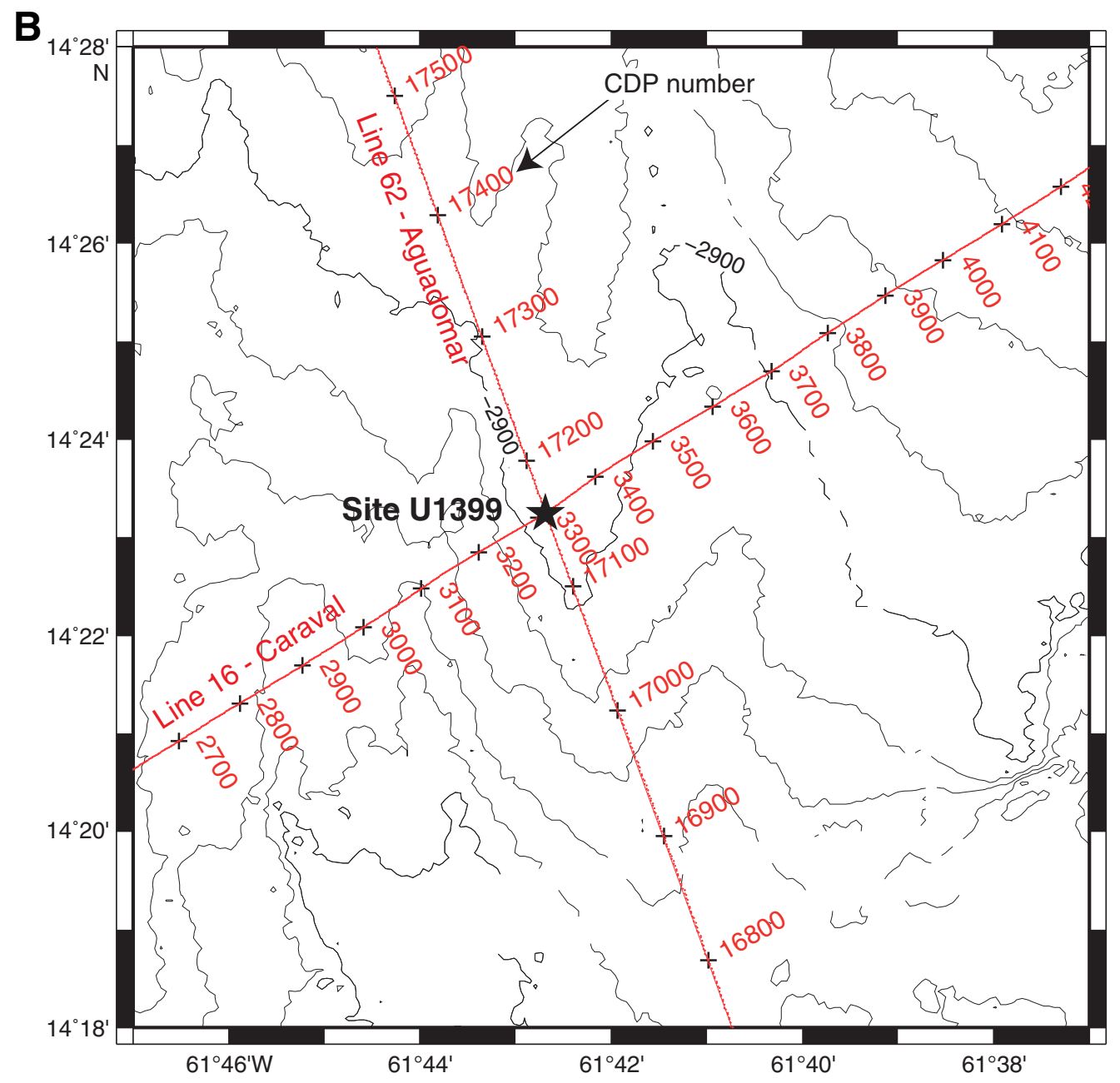


Figure F2. Integrated nannofossil and planktonic foraminiferal biozonation, Site U1399.

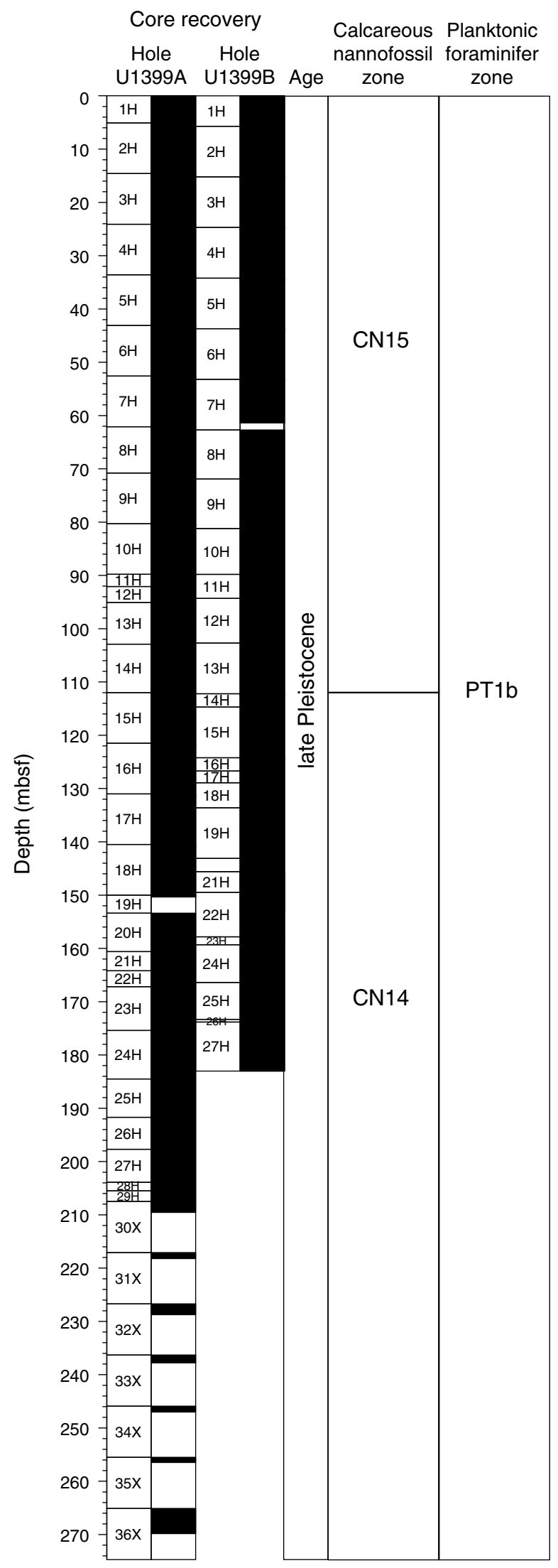


Figure F3. Solid-phase geochemical depth profiles, Site U1399. A. $\mathrm{CaCO}_{3}$. B. Organic carbon.

A

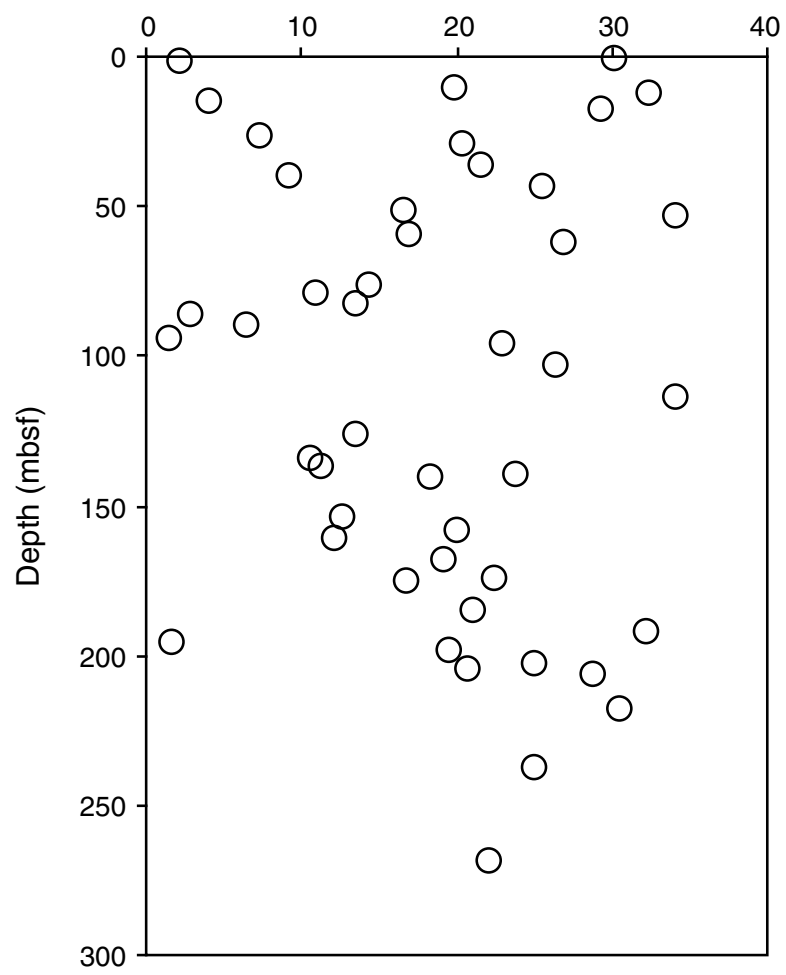

B Organic carbon (wt\%)

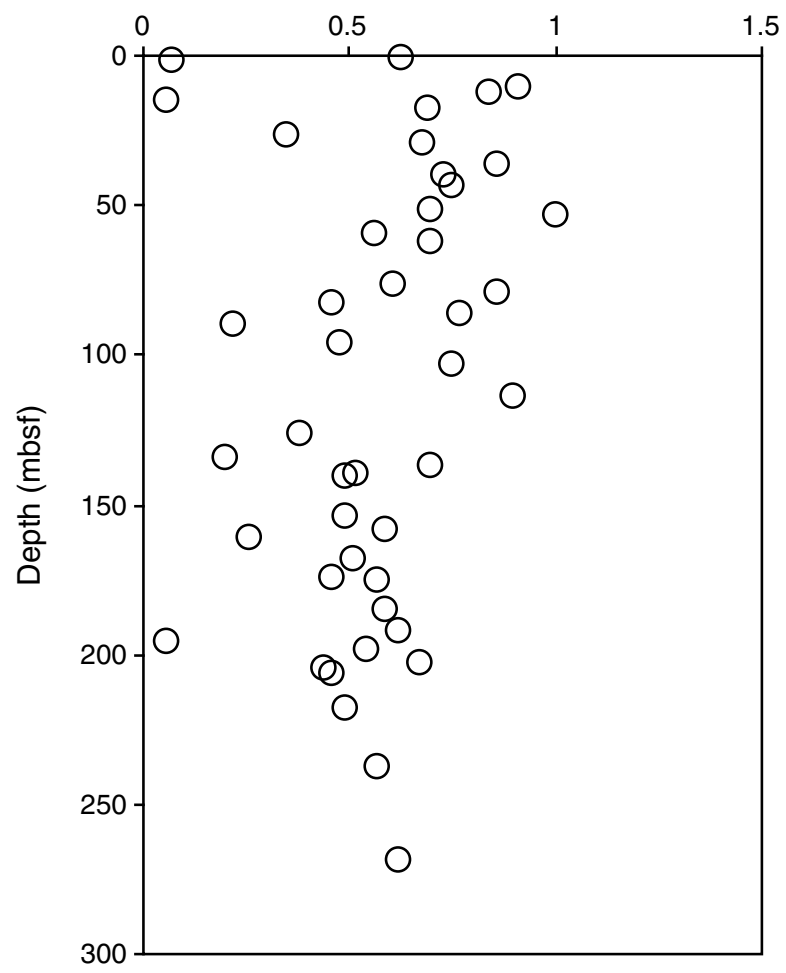




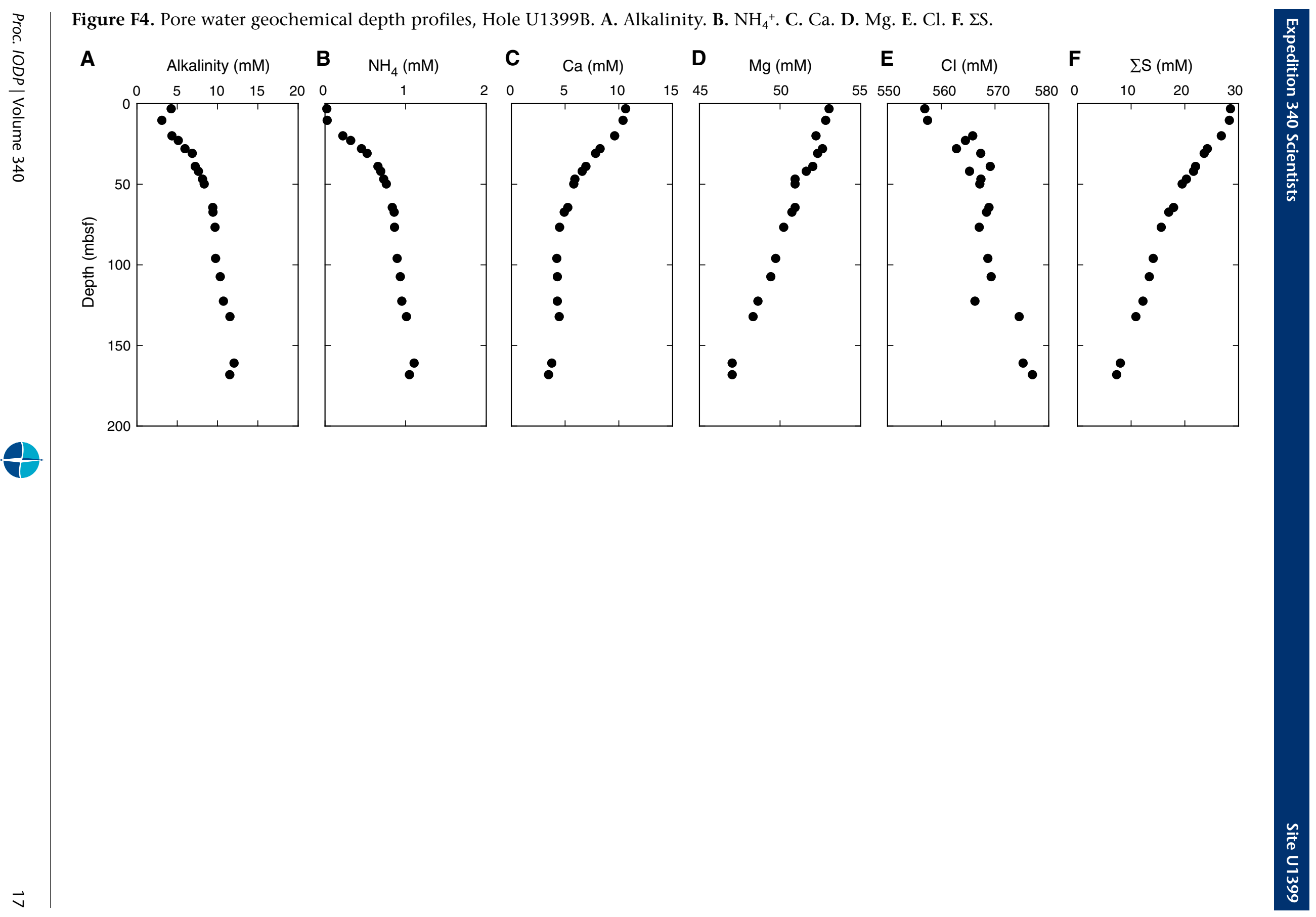


Figure F5. Magnetic susceptibility correlation, Hole U1399B (blue) to Hole U1399A (red). Magnetic susceptibility was measured on the WholeRound Multisensor Logger (WRMSL). Negative values in the last column indicate a downhole shift. A. 0-100 mbsf. (Continued on next page.)

A

$$
\begin{gathered}
\text { Hole U1399A } \\
\text { magnetic susceptibility }
\end{gathered}
$$
$\left(10^{-5} \mathrm{SI}\right)$

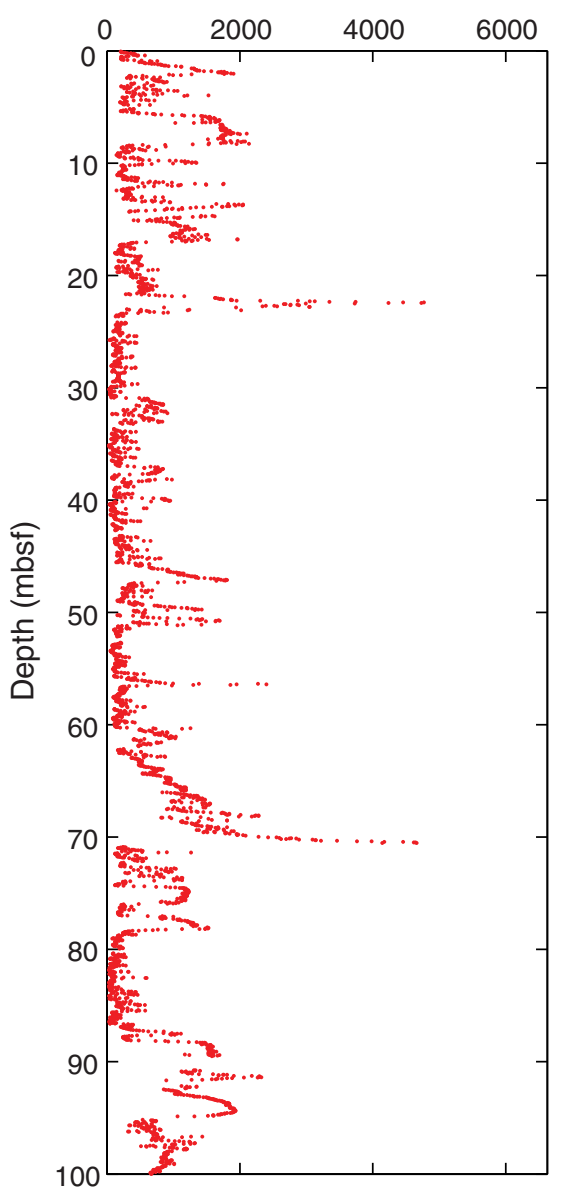

Hole U1399B

magnetic susceptibility

$$
\left(10^{-5} \mathrm{SI}\right)
$$

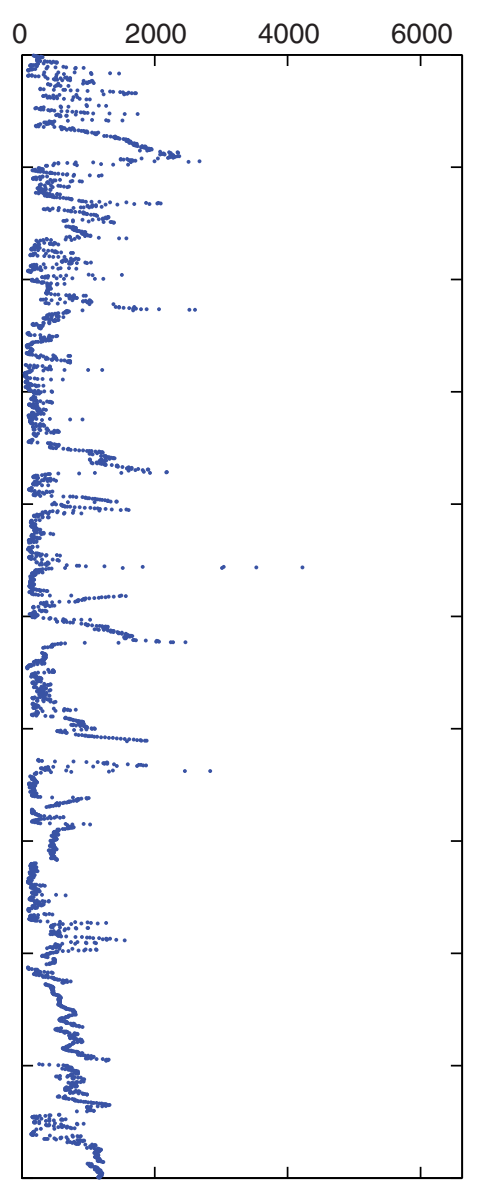

Correlated magnetic susceptibility Hole U1399B to Hole U1399A

$$
\left(10^{-5} \mathrm{SI}\right)
$$

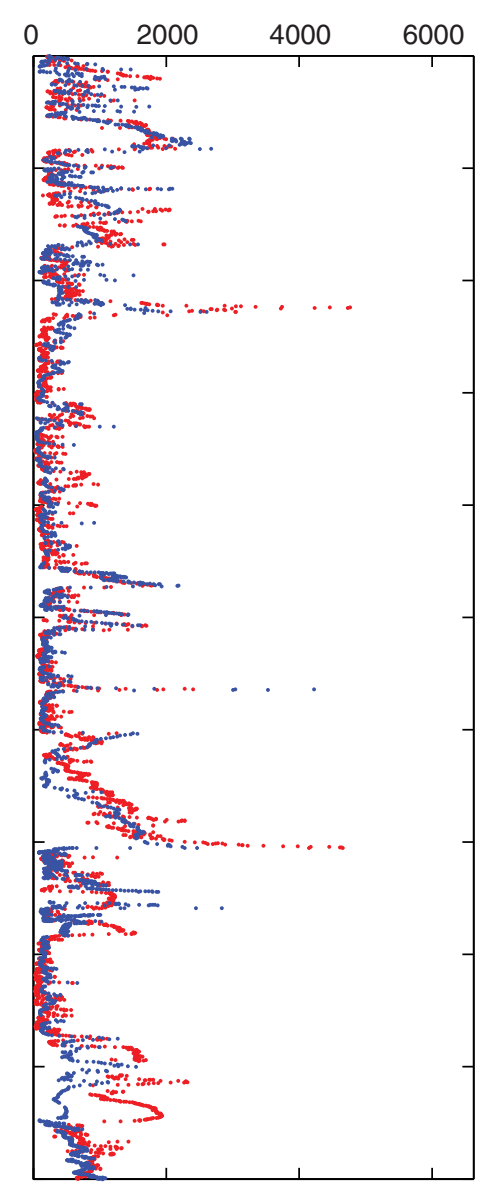

Hole U1399B shift in depth

(m)

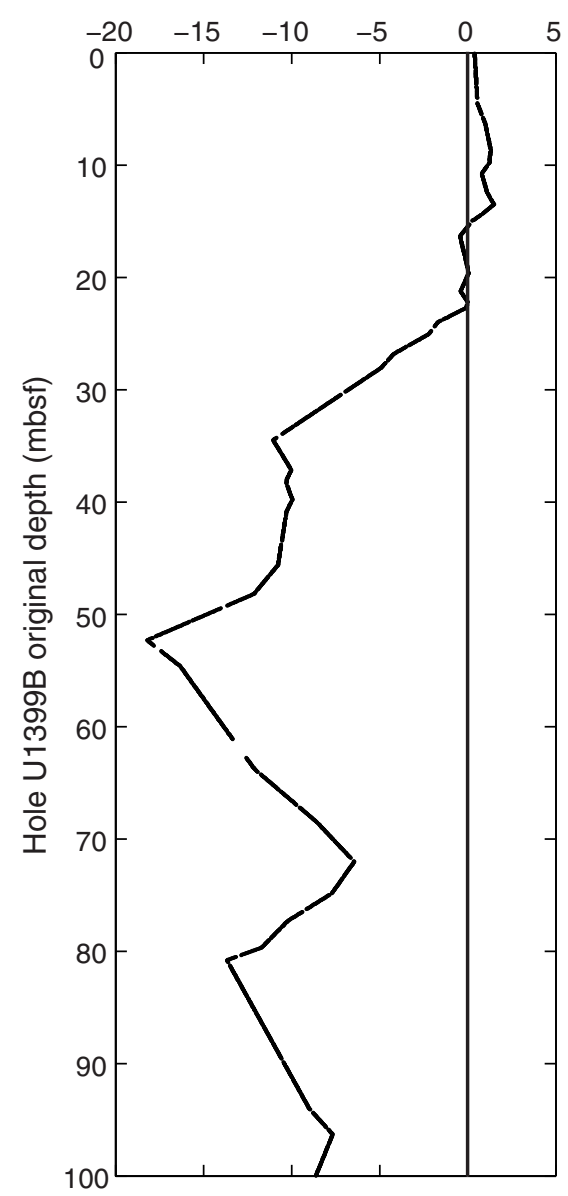



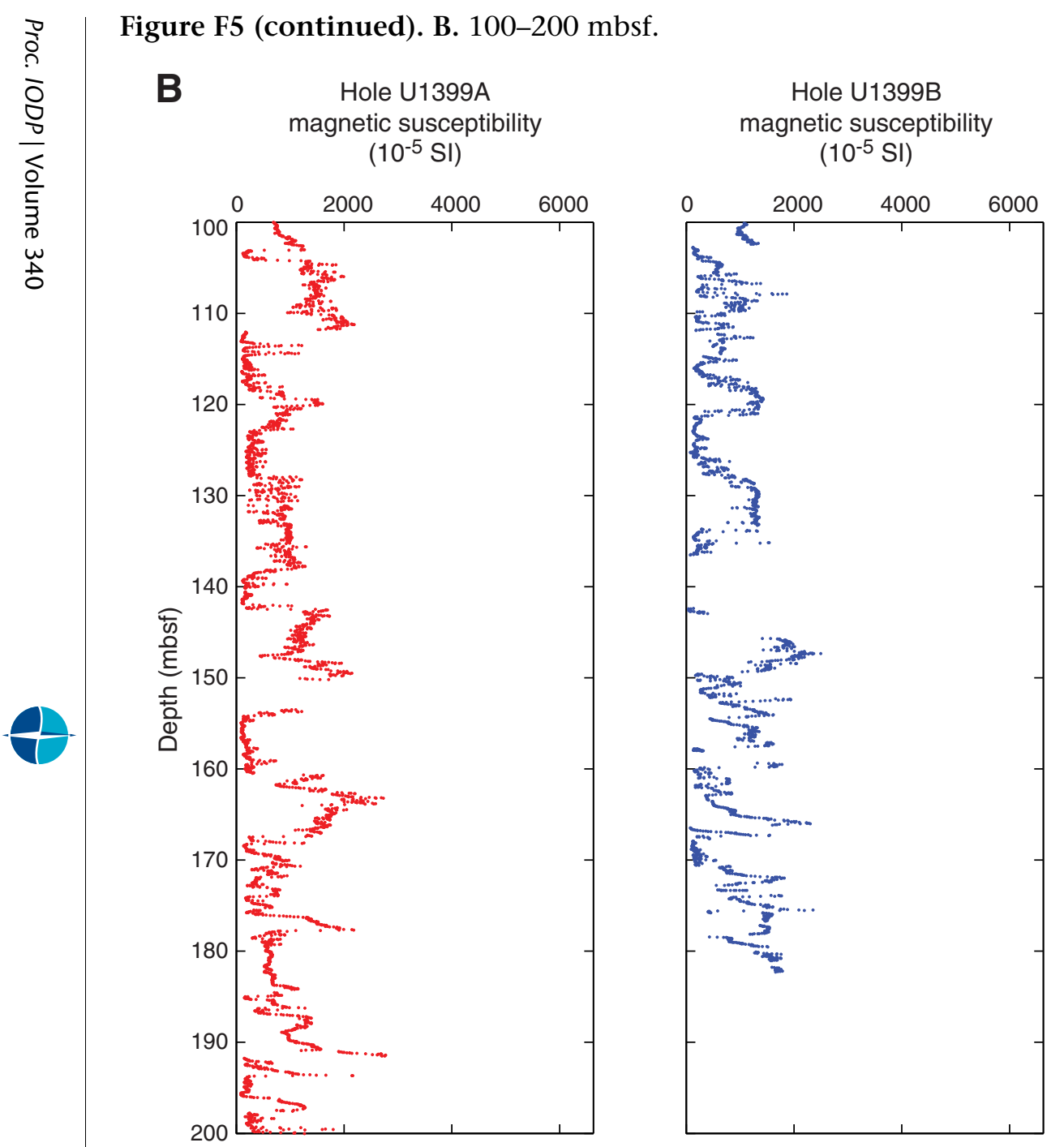

Correlated magnetic susceptibility Hole U1399B to Hole U1399A $\left(10^{-5} \mathrm{SI}\right)$

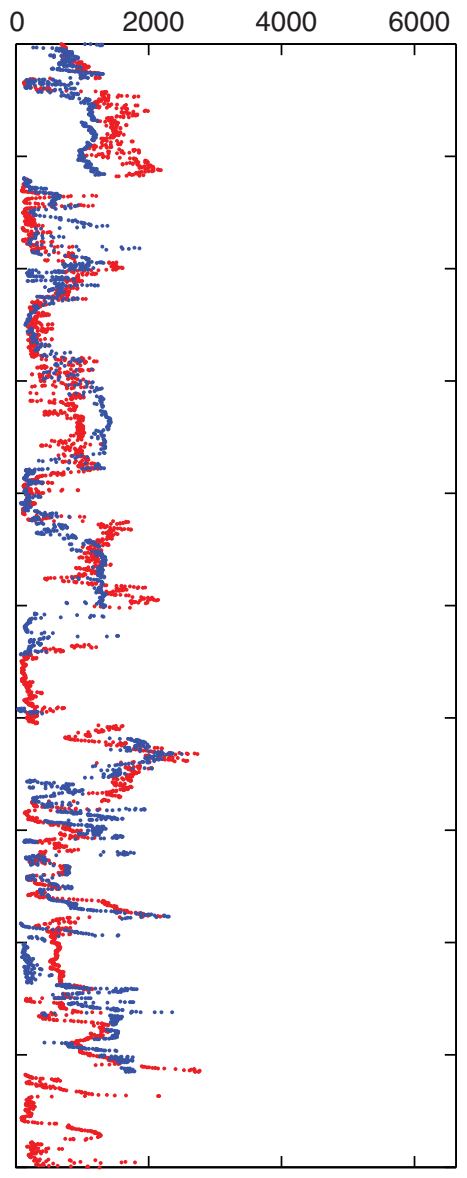

Hole U1399B shift in depth (m)

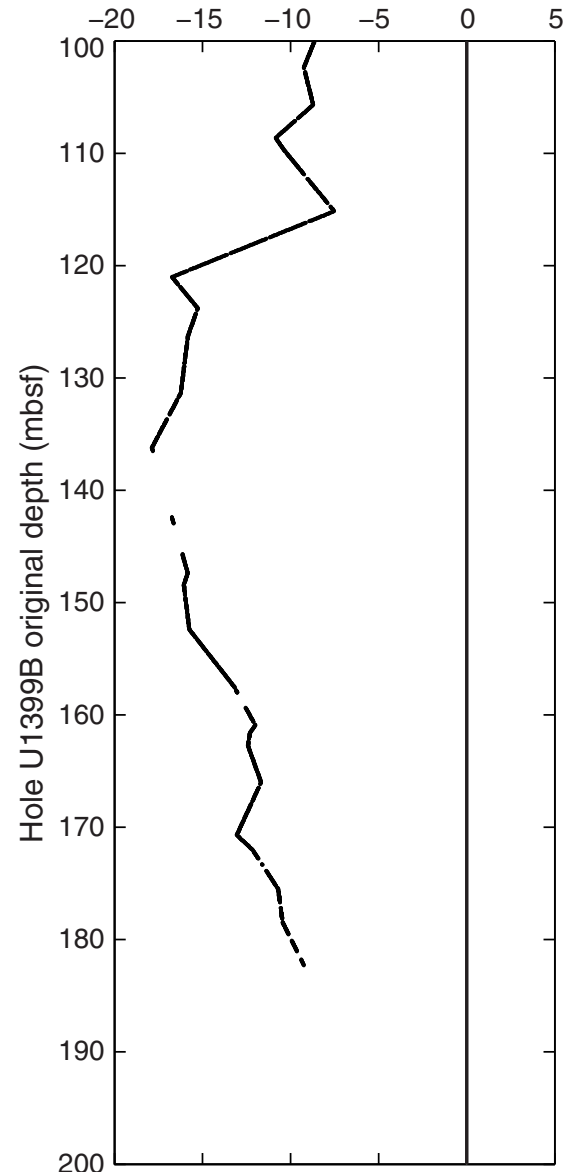


Figure F6. Physical properties, Holes U1399A (red) and U1399B (blue). AVS = automated vane shear. Small points indicate measurements on whole cores using the Whole-Round Multisensor Logger (WRMSL) or Natural Gamma Radiation Logger (NGRL). Larger circles indicate spot measurements obtained from samples of the split working half of the core. $P$-wave velocity was run on the WRMSL.

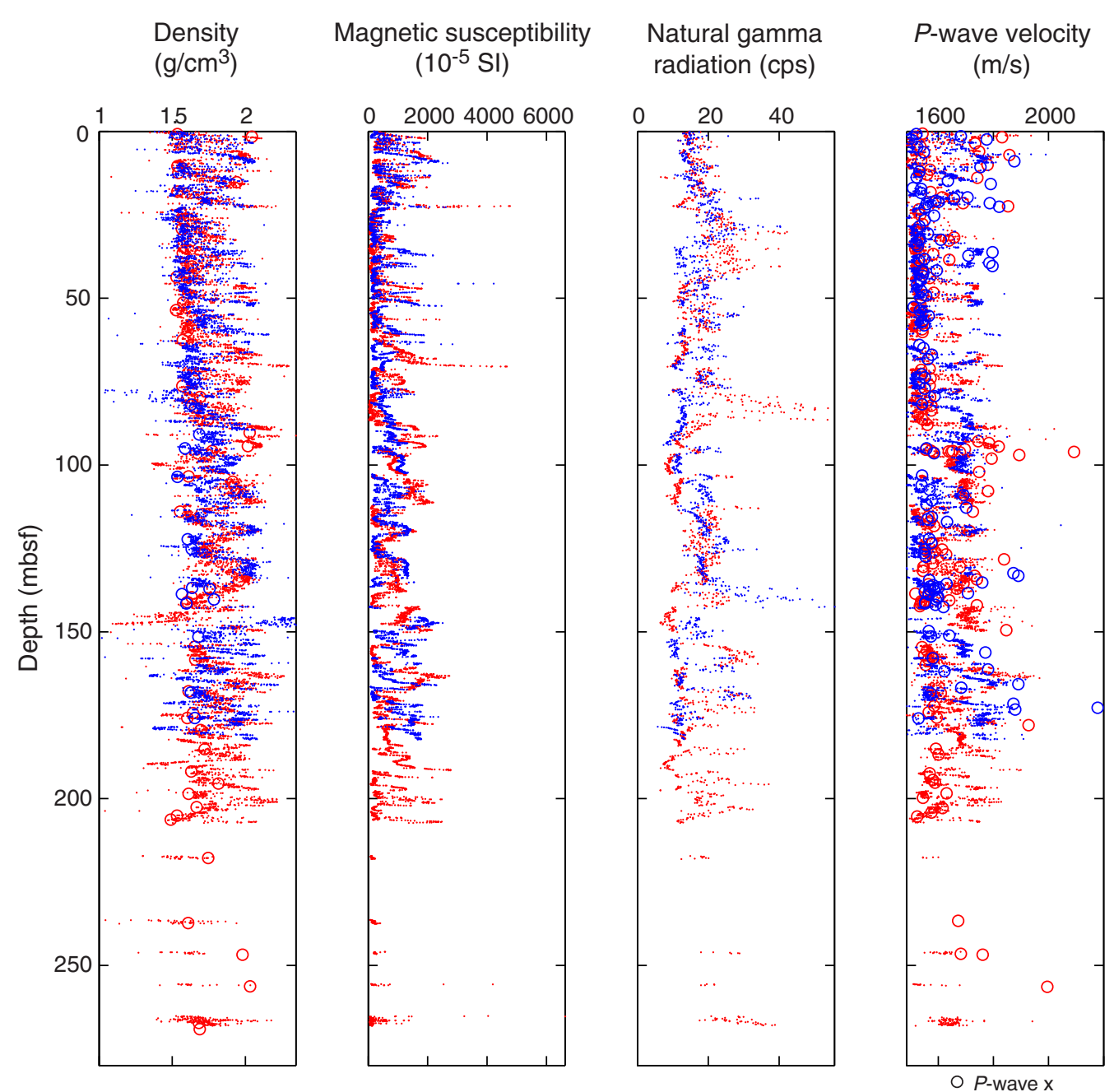

Shear strength

(kPa)

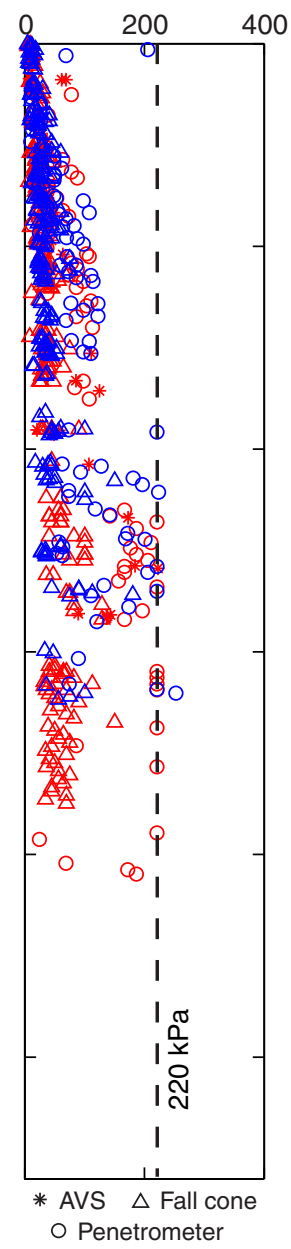

Porosity

(\%)

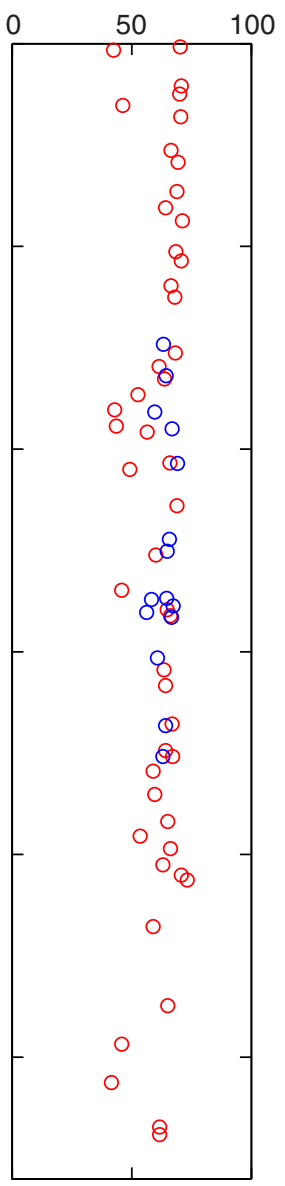

Thermal conductivity $(\mathrm{W} /[\mathrm{m} \cdot \mathrm{K}])$

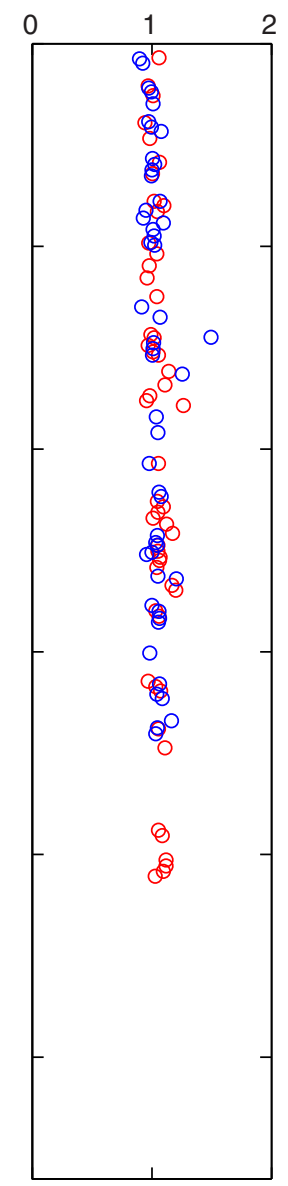


Figure F7. Undrained shear strength $\left(S_{\mathrm{u}}\right)$ measurements, Holes U1399A and U1399B. Black dashed line indicates depths at which the fall cone (FC) should be considered as a lower bound of $S_{\mathrm{u}}$. Solid black line correlates a major shear surface. AVS = automated vane shear, $\mathrm{PP}=$ pocket penetrometer.

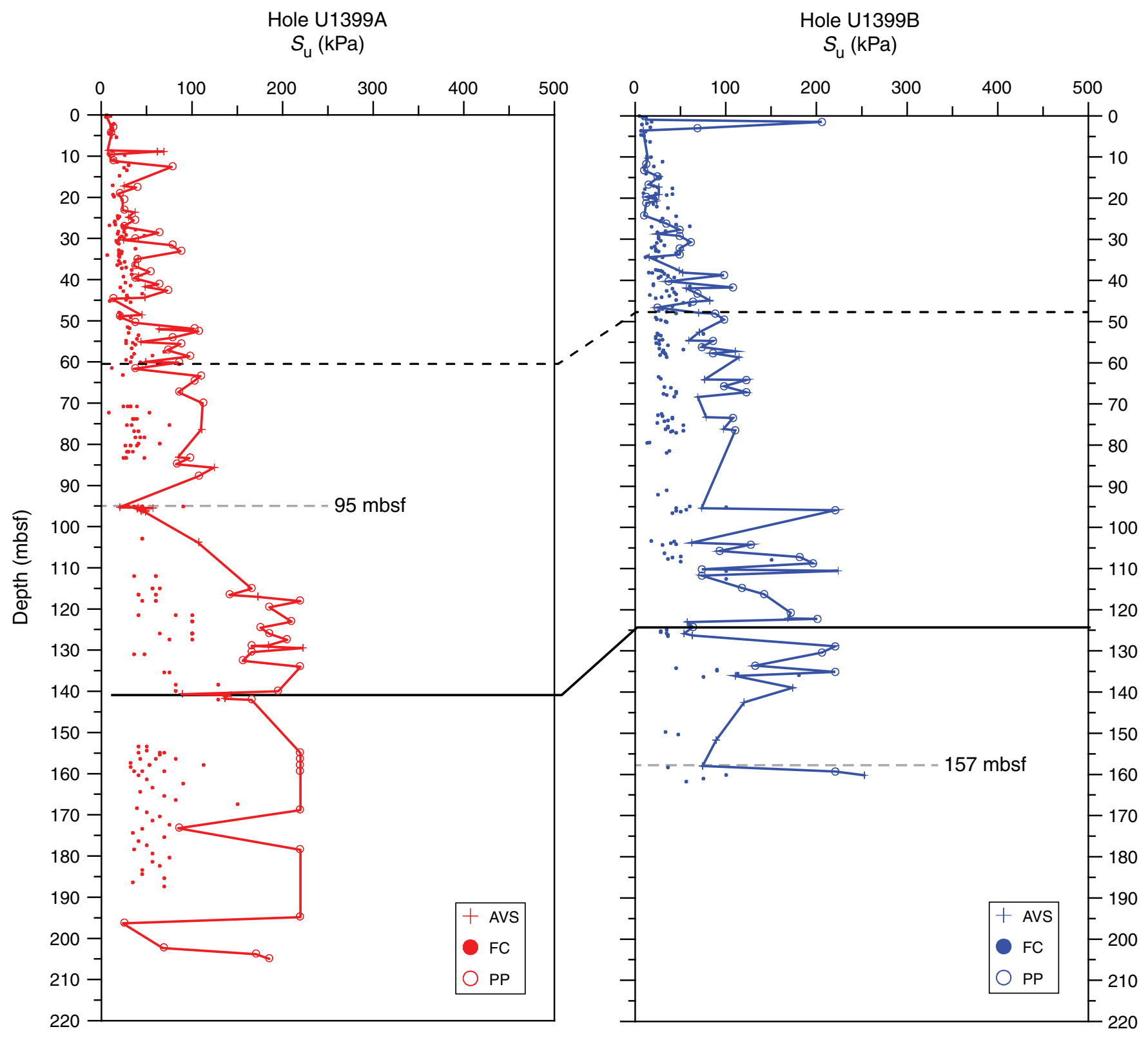


Figure F8. Plots of sensitivity $\left(S_{\mathrm{t}}\right)$ obtained from peak $\left(S_{\mathrm{u}}\right.$ peak) and residual $\left(S_{\mathrm{u}}\right.$ res) strengths and measured during vane shear tests at discrete depths, Holes U1399A and U1399B.
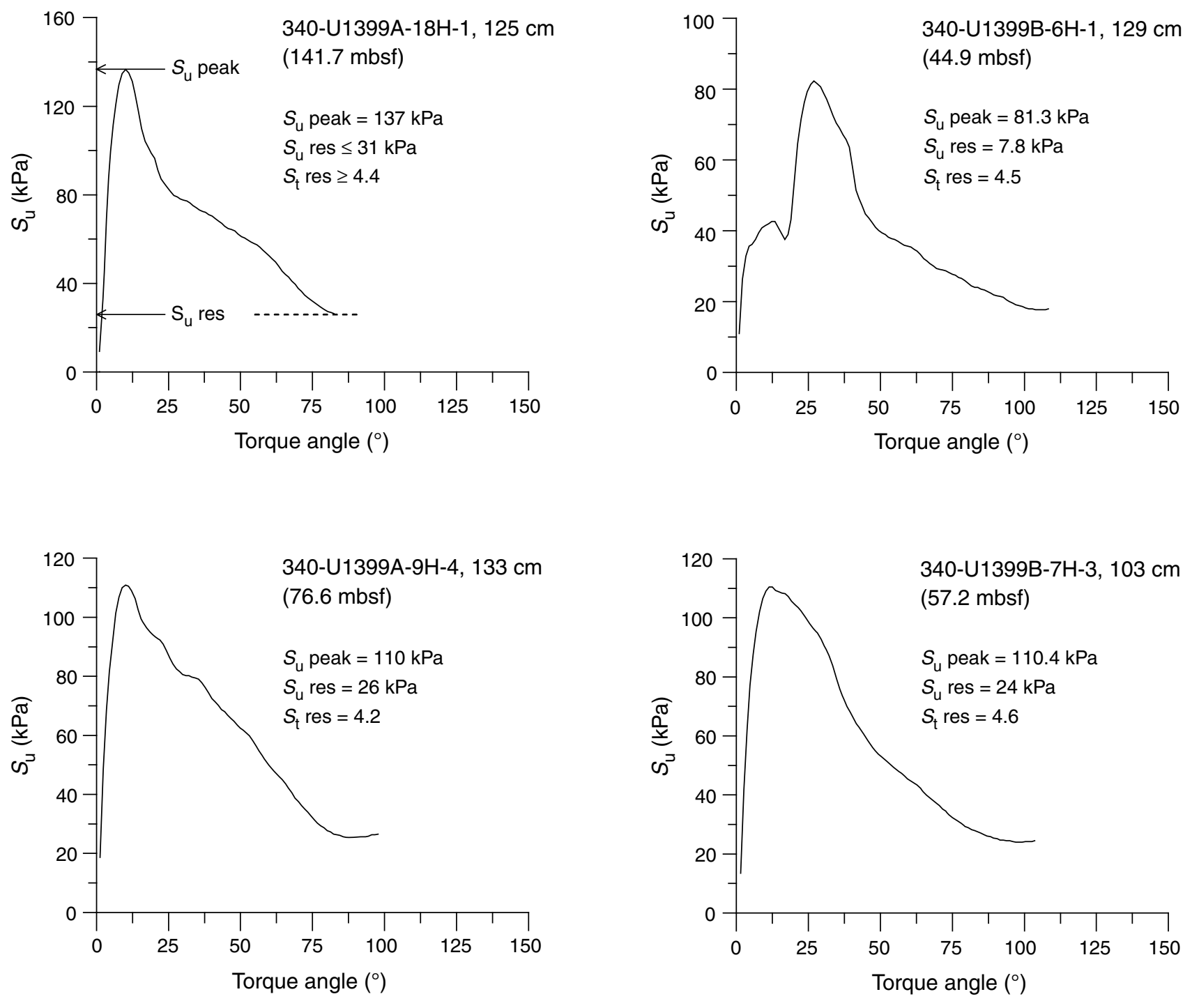
Figure F9. Temperature as a function of depth, Holes U1399A (red) and U1399B (blue). Straight line is a best fit to the measurements.

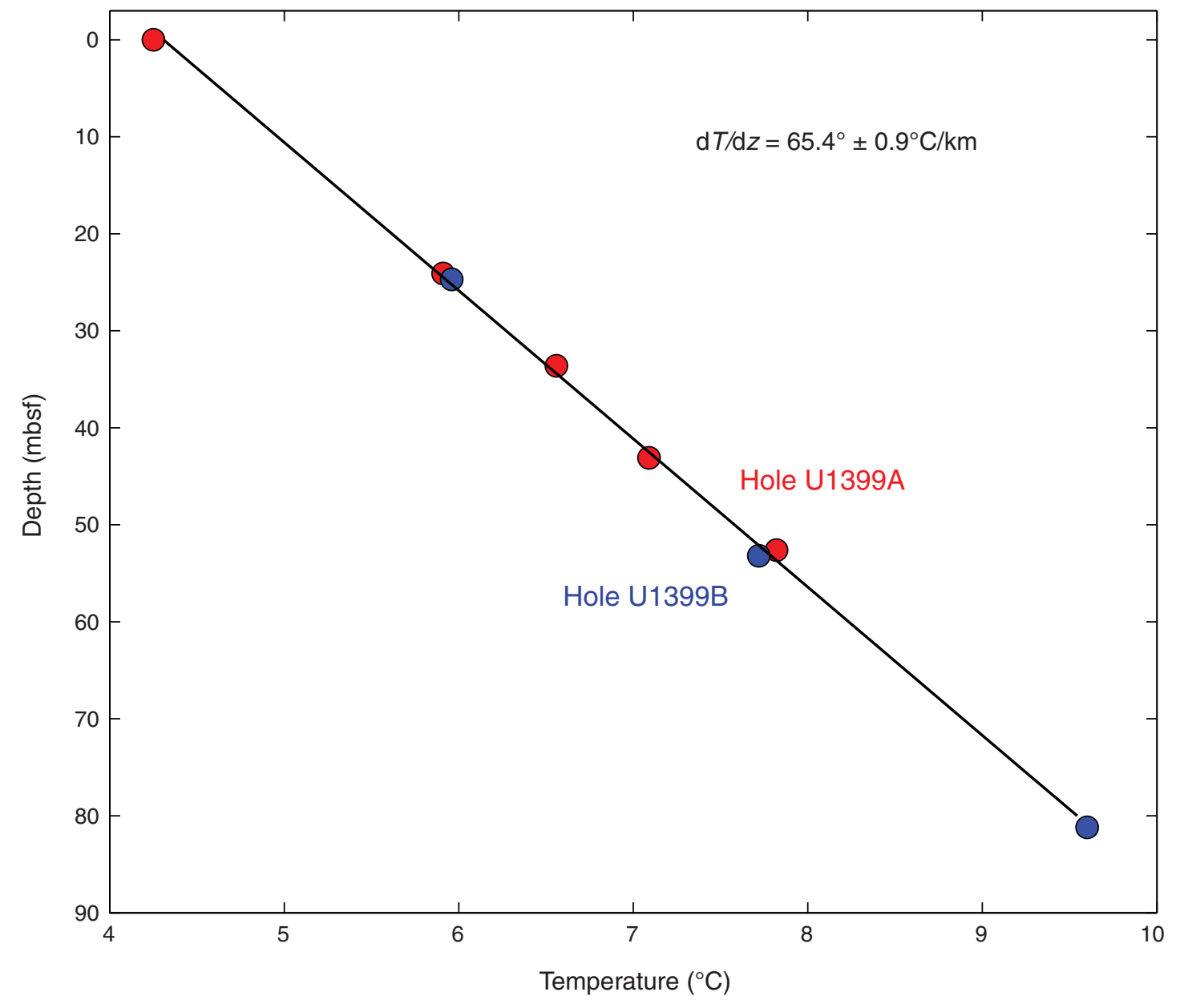


Figure F10. Plots of raw inclination, hemipelagic inclination, and nonchaotic inclination, Hole U1399A. In the core summary column (see "Lithostratigraphy" and "Core descriptions"), black zones indicate turbidites, red zones show ash layers, blue zones are deformed hemipelagic sediment, and green zones are nonchaotic hempelagic sediment.

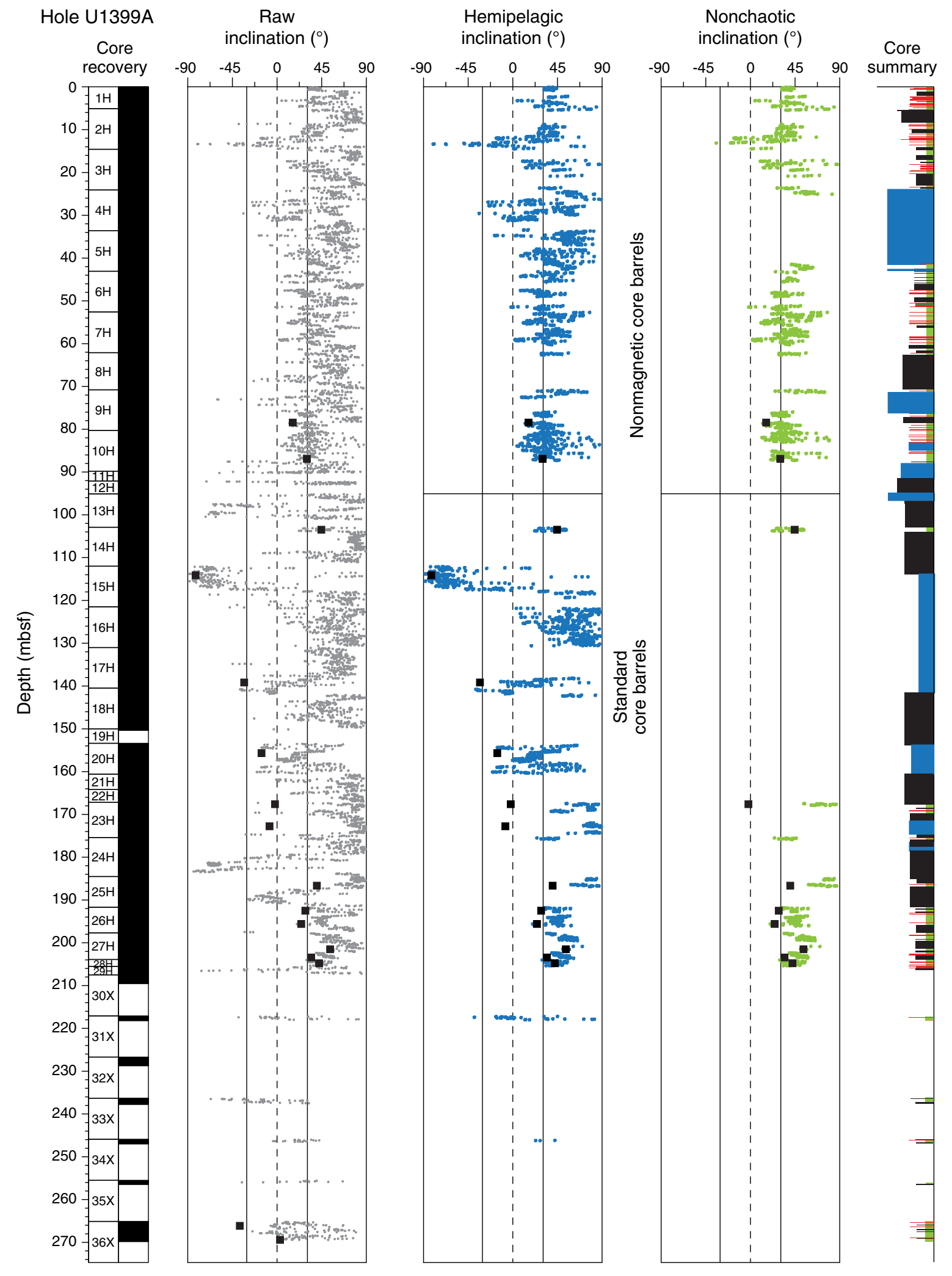


Figure F11. Plots of intensity of $\mathrm{NRM}_{0}$ (red) and $\mathrm{NRM}_{20}$ (blue) and inclination and declination after $20 \mathrm{mT}$ demagnetization, Hole U1399A. For inclination data, gray points are all measurements made and red data are measurements made on hemipelagic sediment. For declination data, gray points are unoriented declinations and red points are FlexIt tool-corrected data on nonchaotic hemipelagic sediment. Orange points are SRM and discrete inclination guided data on nonchaotic hemipelagic sediment. Black squares are discrete declination and inclination measurements shown against a geocentric axial dipole (GAD) inclination of $27.2^{\circ}$.

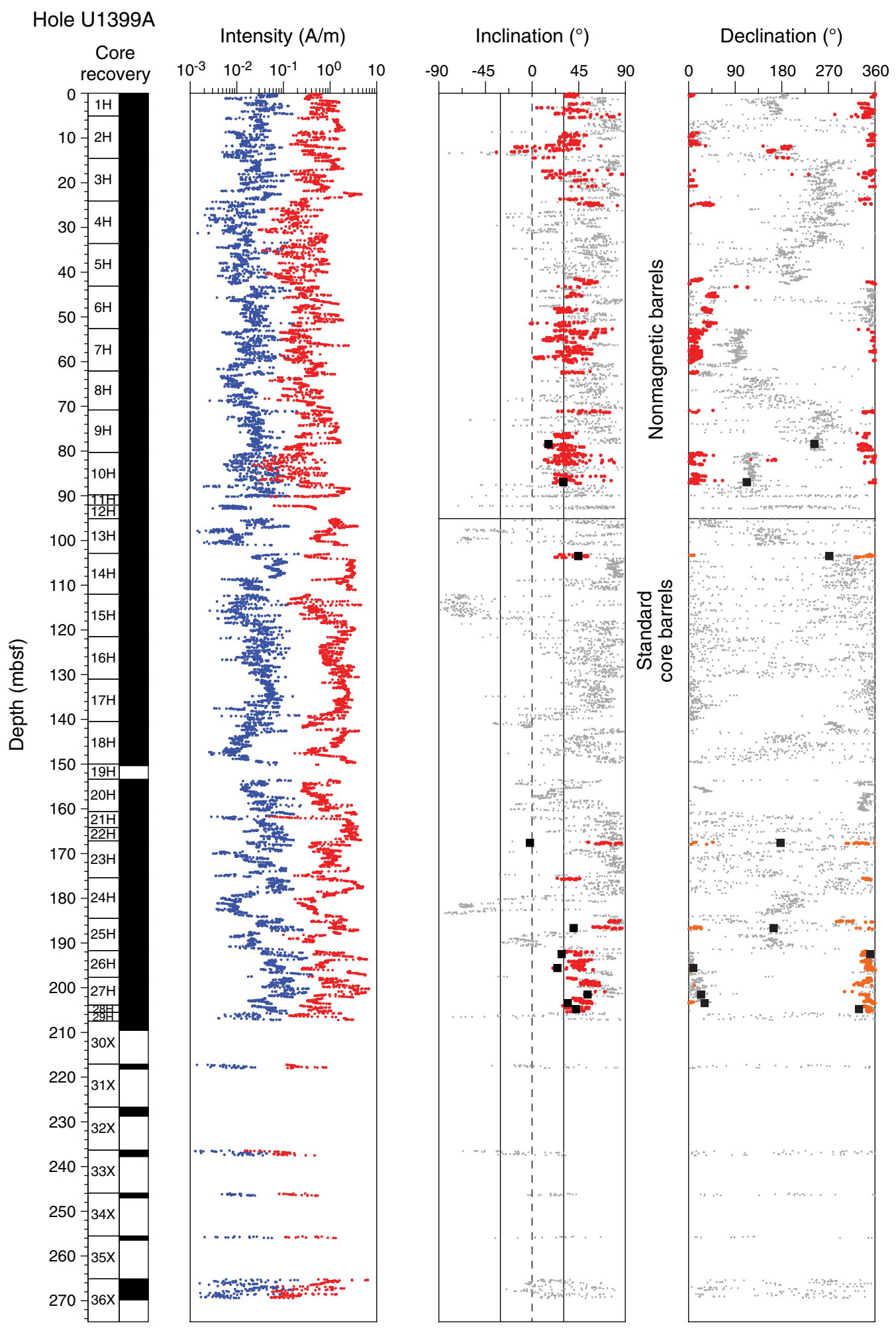


Figure F12. Plots of intensity of $\mathrm{NRM}_{0}$ (red) and $\mathrm{NRM}_{20}$ (blue) and inclination and declination after $20 \mathrm{mT}$ demagnetization, Hole U1399B. For inclination data, gray points are all measurements made and red data are measurements made on hemipelagic sediment. For declination data, gray points are unoriented declinations and red points are FlexIt tool-corrected data on nonchaotic hemipelagic sediment. Orange points are SRM and discrete inclination guided data on nonchaotic hemipelagic sediment. Black squares are discrete declination and inclination measurements shown against a geocentric axial dipole (GAD) inclination of $27.2^{\circ}$.

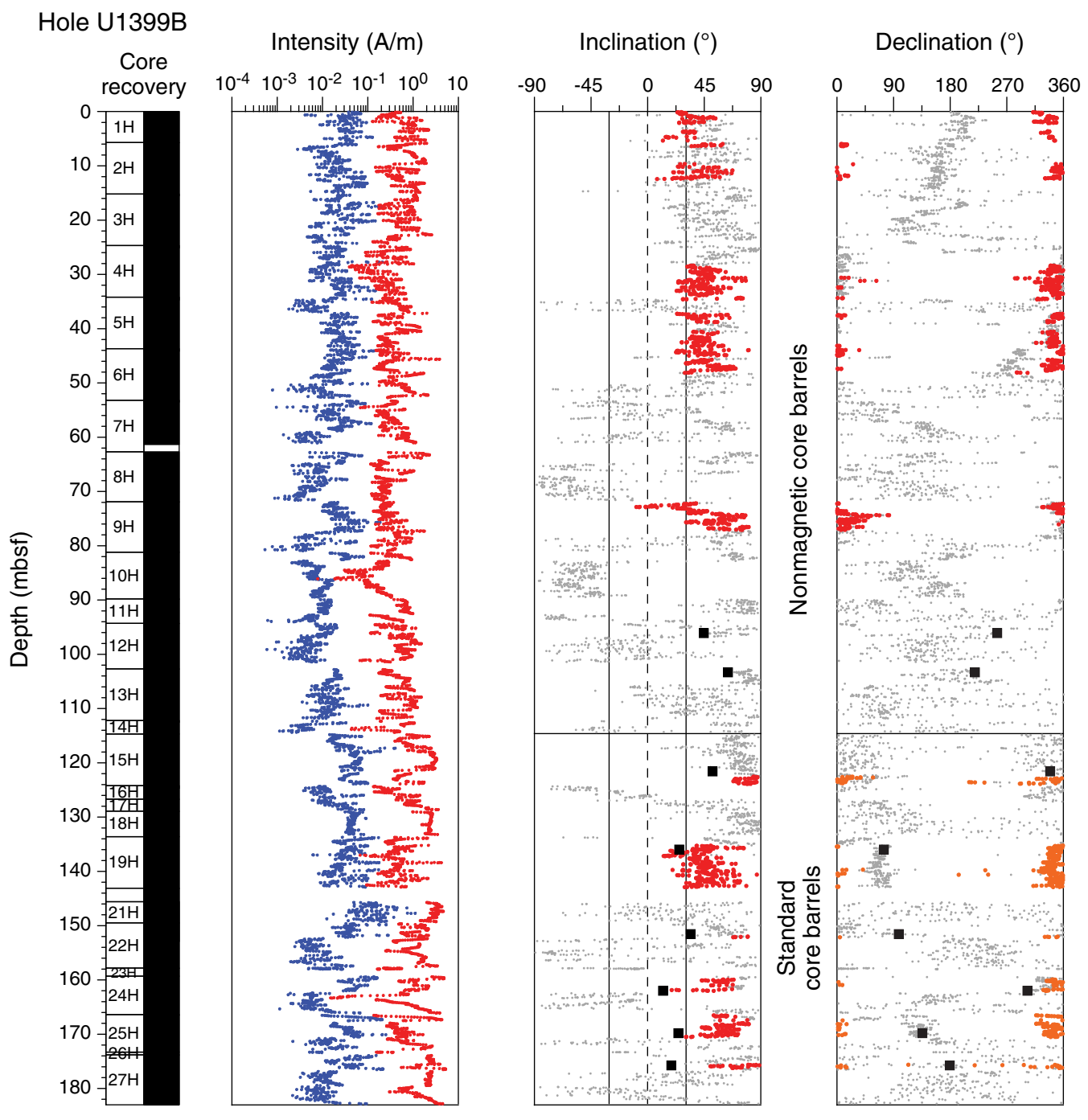


Figure F13. Schematic of tool deployments in Hole U1399C, indicating the degree of infill through the course of the logging program. MSS = Magnetic Susceptibility Sonde, VSI = Versatile Seismic Imager, FMS = Formation MicroScanner. TD = total depth. Stars indicate the eight vertical seismic profile (VSP) stations.

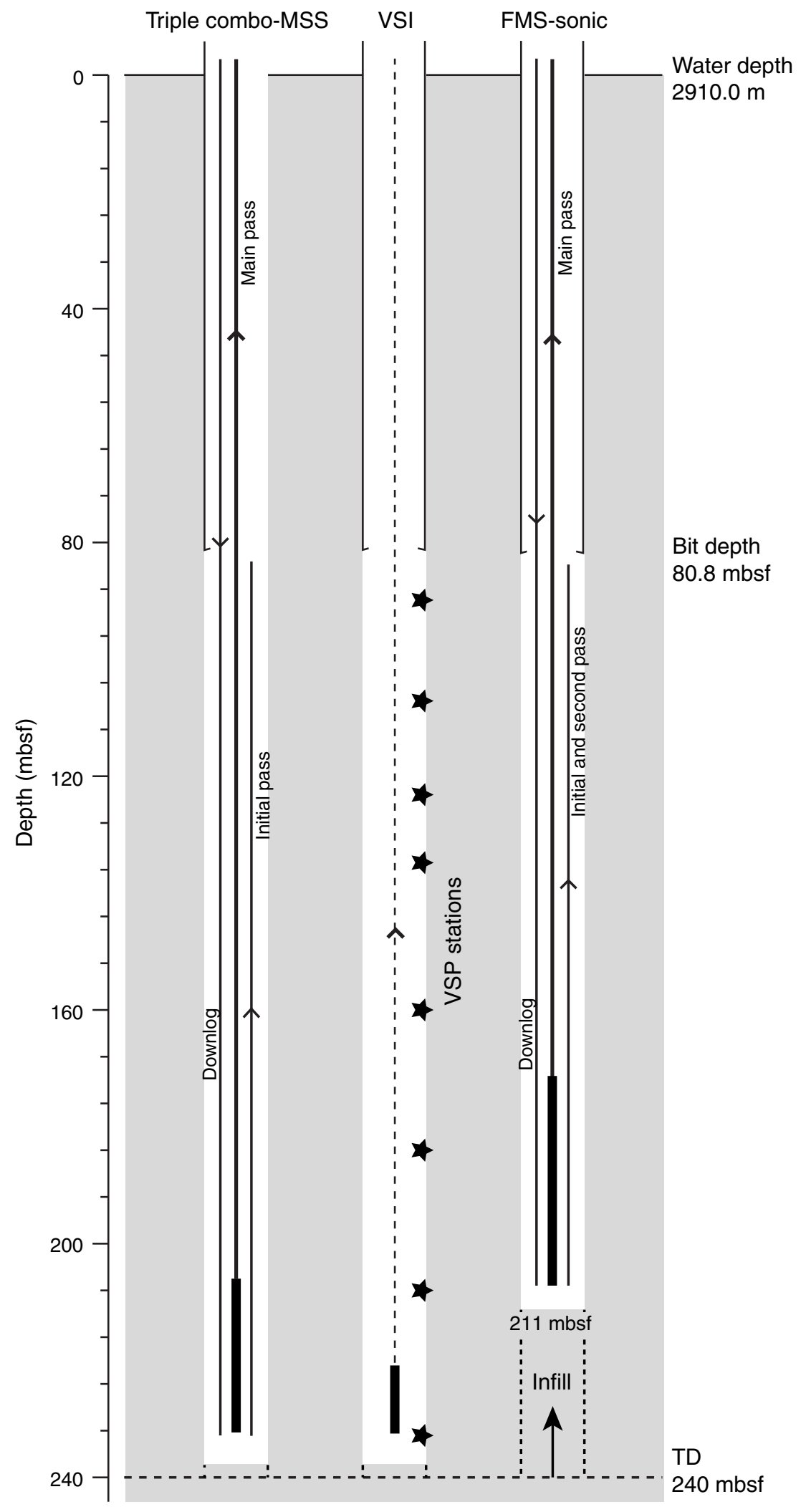


Figure F14. Summary of logs recorded by the modified triple combo tool string in Hole U1399C and comparison to natural gamma radiation (NGR) data from the recovered cores from Hole U1399A. High-Resolution Laterolog Array (HRLA) readings: R3 = medium resistivity, R5 = deepest resistivity, RT = true resistivity, modeled from all depths of investigation. uncal $=$ uncalibrated units.

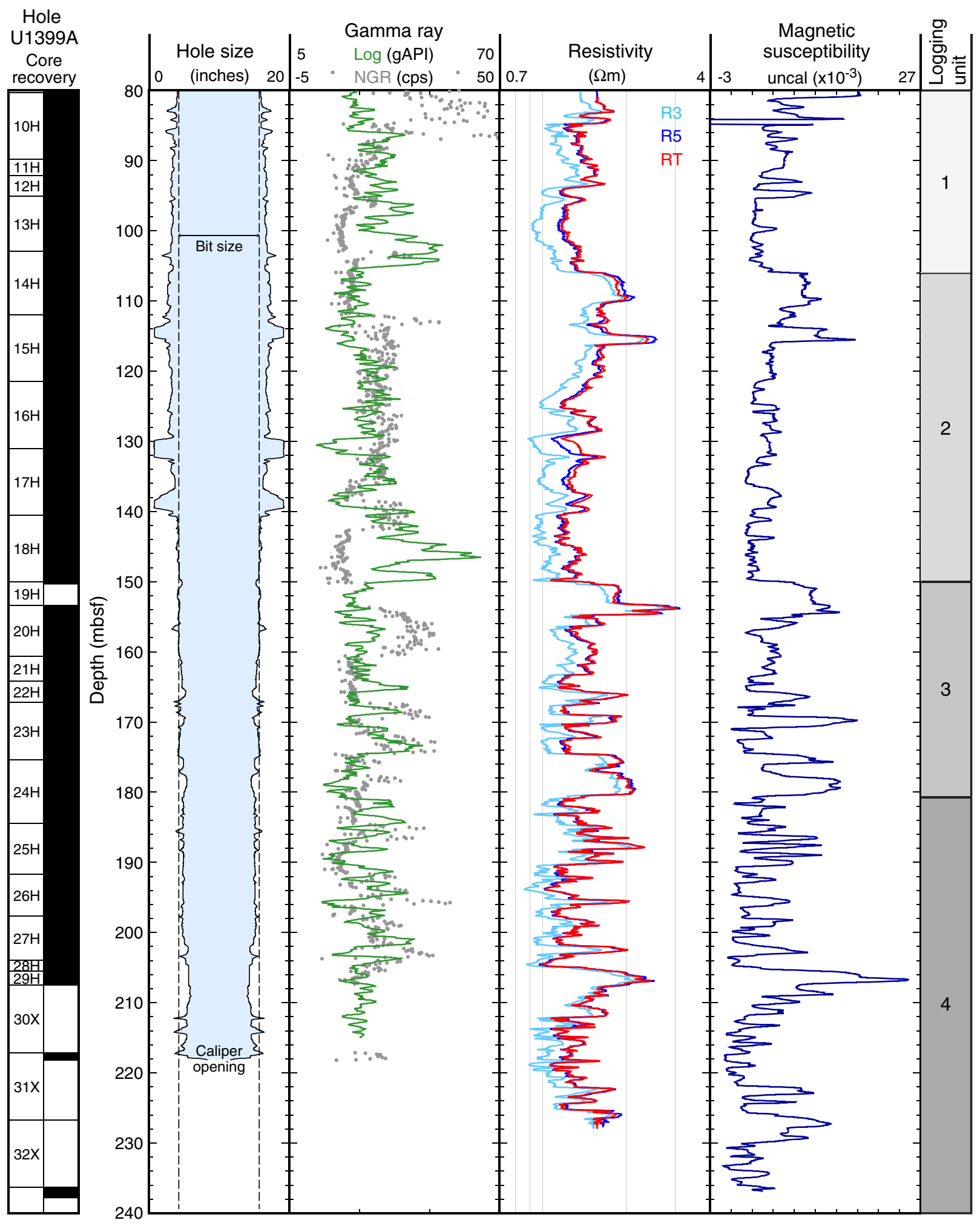


Figure F15. Summary of logs recorded by the modified Formation MicroScanner (FMS)-sonic tool string, Hole U1399C. Hole size is measured by the two orthogonal calipers of the FMS (C1 and C2). Gamma ray recorded during the FMS-sonic run is compared to gamma ray recorded by the triple combo run (TC). Total gamma ray from the Hostile Environment Natural Gamma Ray Sonde (HNGS) is shown alongside natural gamma radiation (NGR) data from Hole U1399A cores. The high waveform coherence, in red in the velocity tracks, is a measure of the reliability of the slowness/time coherence algorithm used to derive compressional $\left(V_{\mathrm{p}}\right)$ and shear $\left(V_{\mathrm{S}}\right)$ wave velocities from the monopole and lower dipole sonic waveforms, respectively. EDTC = Enhanced Digital Telemetry Cartridge. (Figure shown on next page.) 
Figure F15 (continued). (Caption shown on previous page.)

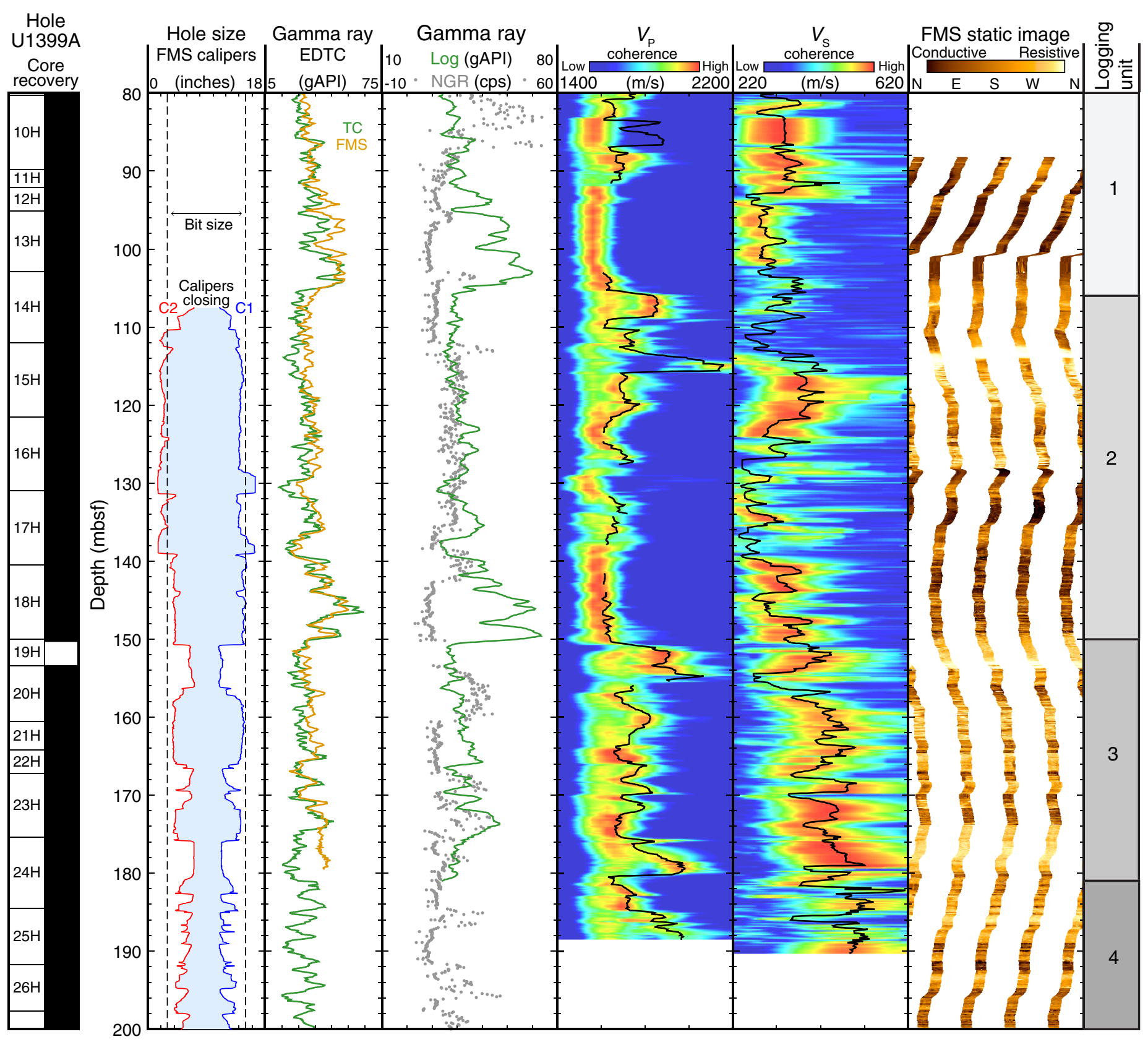


Figure F16. Summary of spectral natural gamma radiation measurements, Hole U1399C. SGR = total gamma ray; $\mathrm{CGR}=$ computed gamma ray, or gamma ray without the contribution of uranium. The area between the two curves shows the contribution of uranium, a common indicator of organic content.

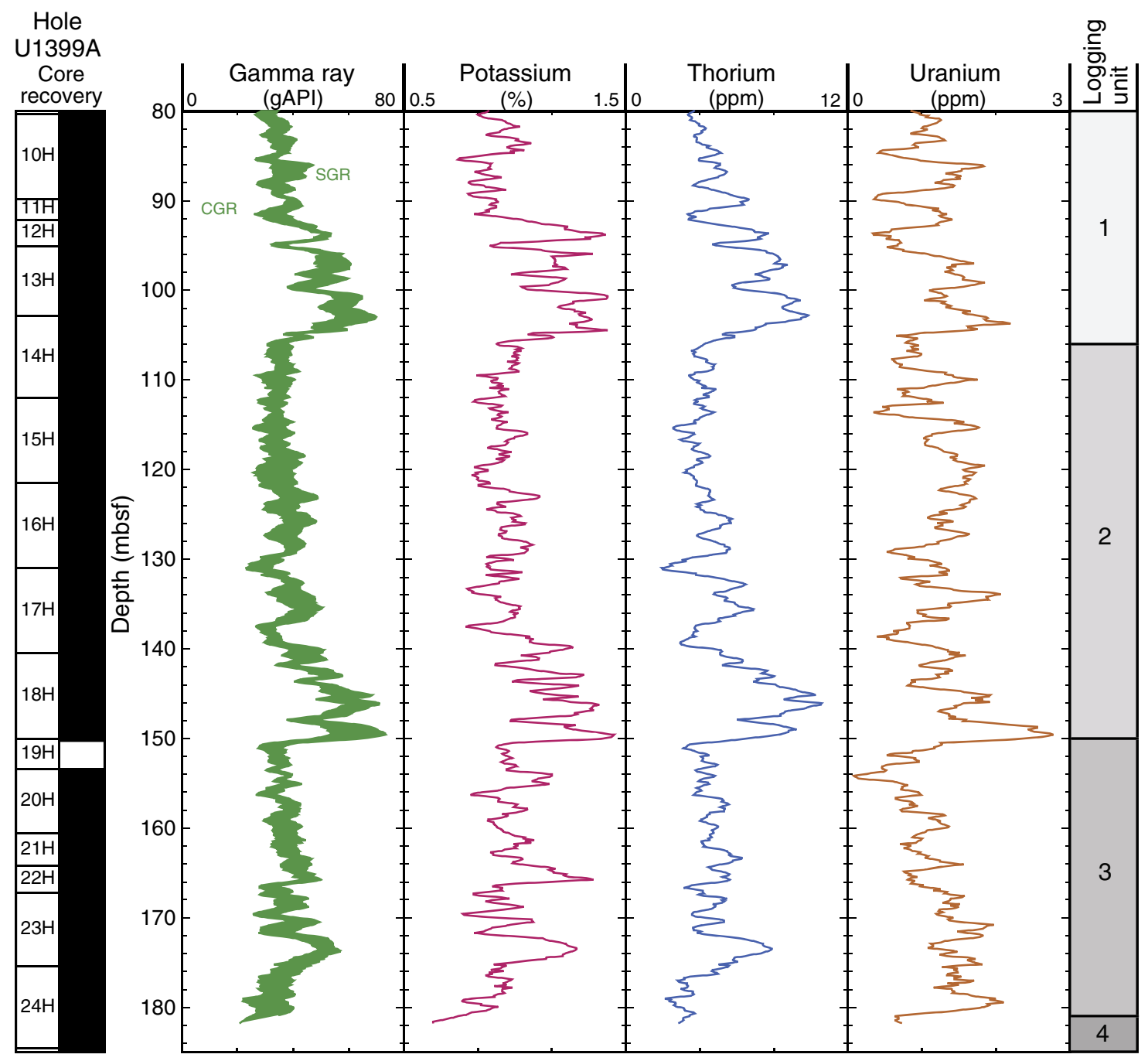


Figure F17. Vertical seismic profile (VSP) waveforms and one-way traveltime picks (green crosses), Hole U1399C. Seismic waveforms are stacked from multiple records at each station.

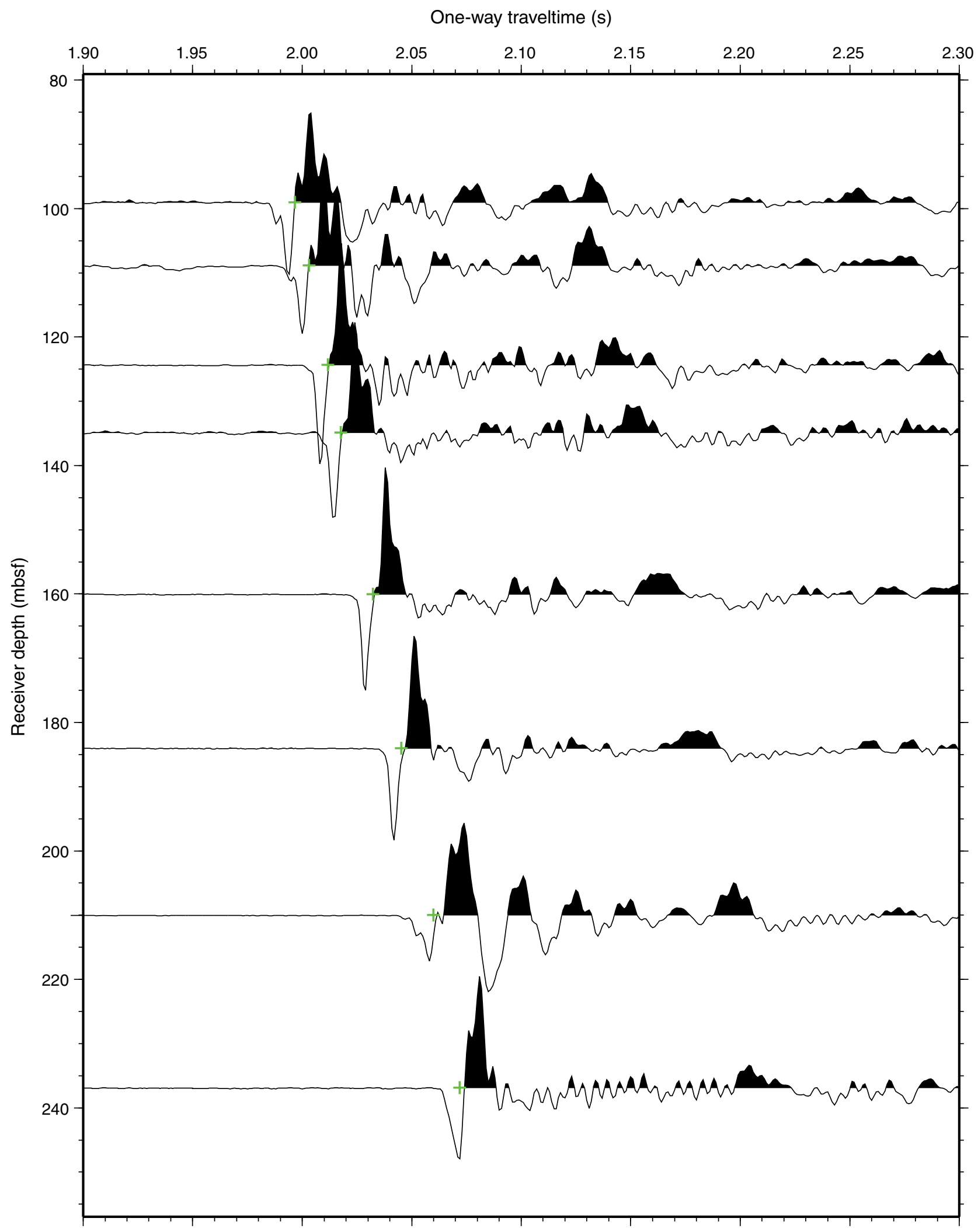


Figure F18. Comparison of some of the main logs recorded during multiple logging passes, Hole U1399C. There is very good agreement between the two passes, indicating the reliability of the various measurements. uncal = uncalibrated units.

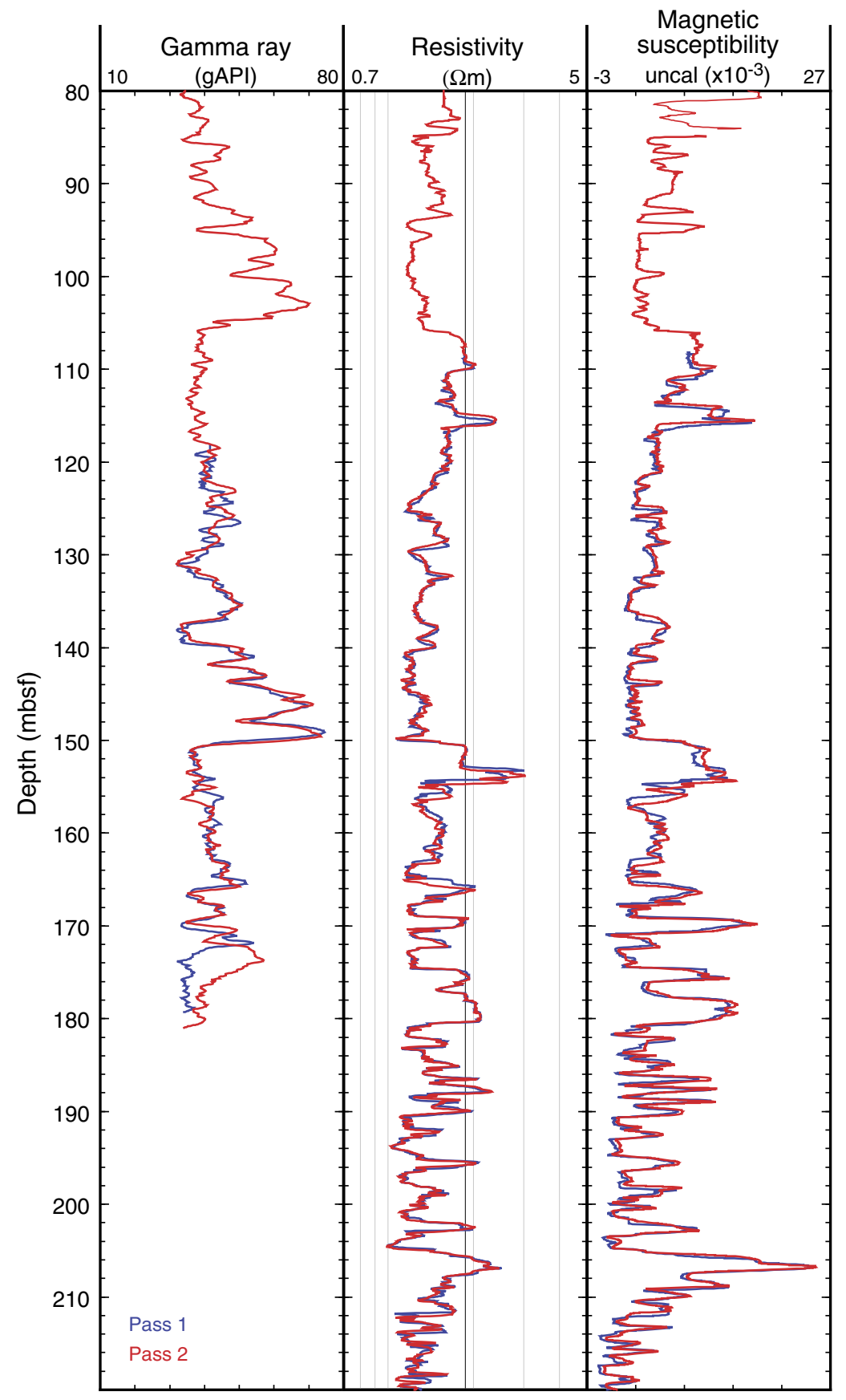


Figure F19. Comparison of traveltime data from the vertical seismic profile (VSP) experiment and FMS-sonic tool string acquired in Hole U1399C vs. predicted velocity for Site U1399. Red stars indicate the eight VSP measurement stations. Time from the sonic tool is derived from compressional wave velocity $\left(V_{\mathrm{p}}\right)$ measurements.

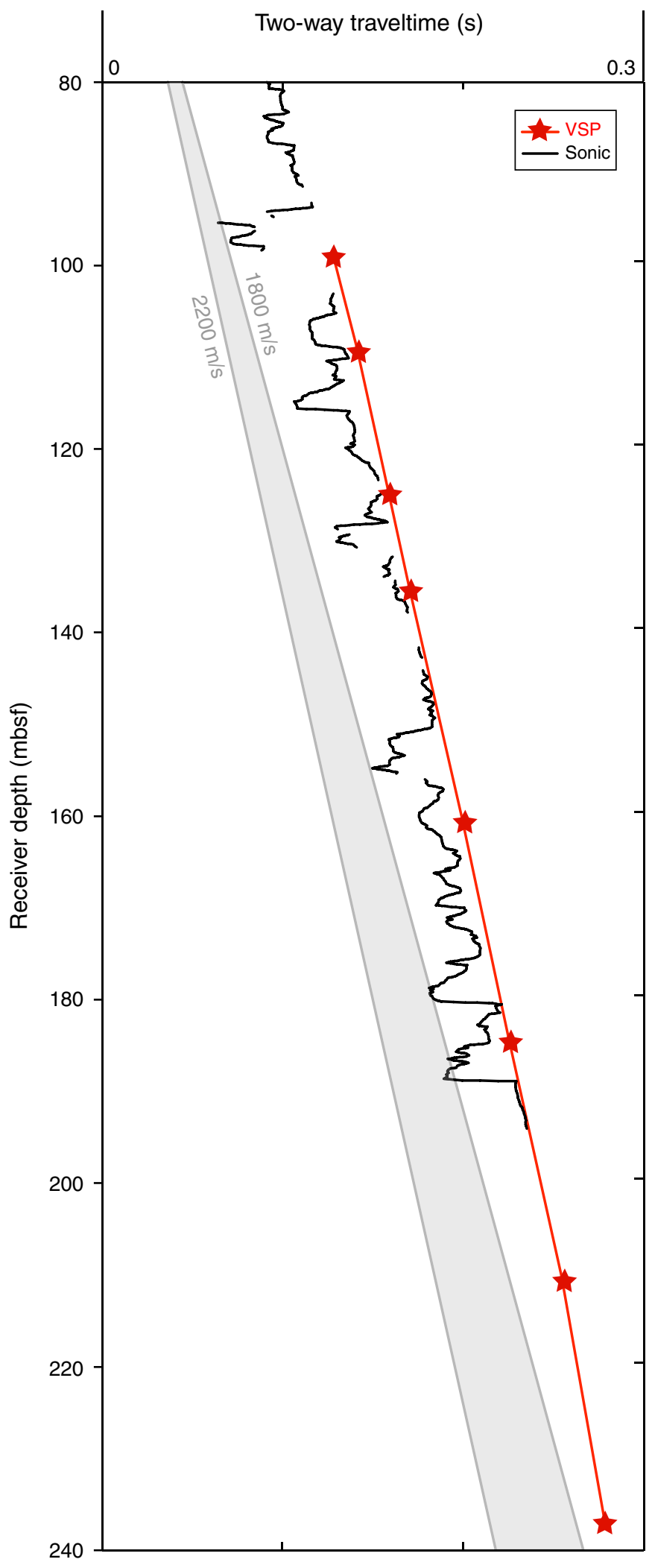


Figure F20. Examples of statically processed FMS images, Hole U1399C. Paler colors represent more resistive material and darker colors indicate more conductive material. A. FMS image from 160.0 to 161.5 mbsf. Example of some of the textures encountered in the transition zone. B. Example of a range of resistivities encountered across a small interval (123.5-125.0 mbsf).

A

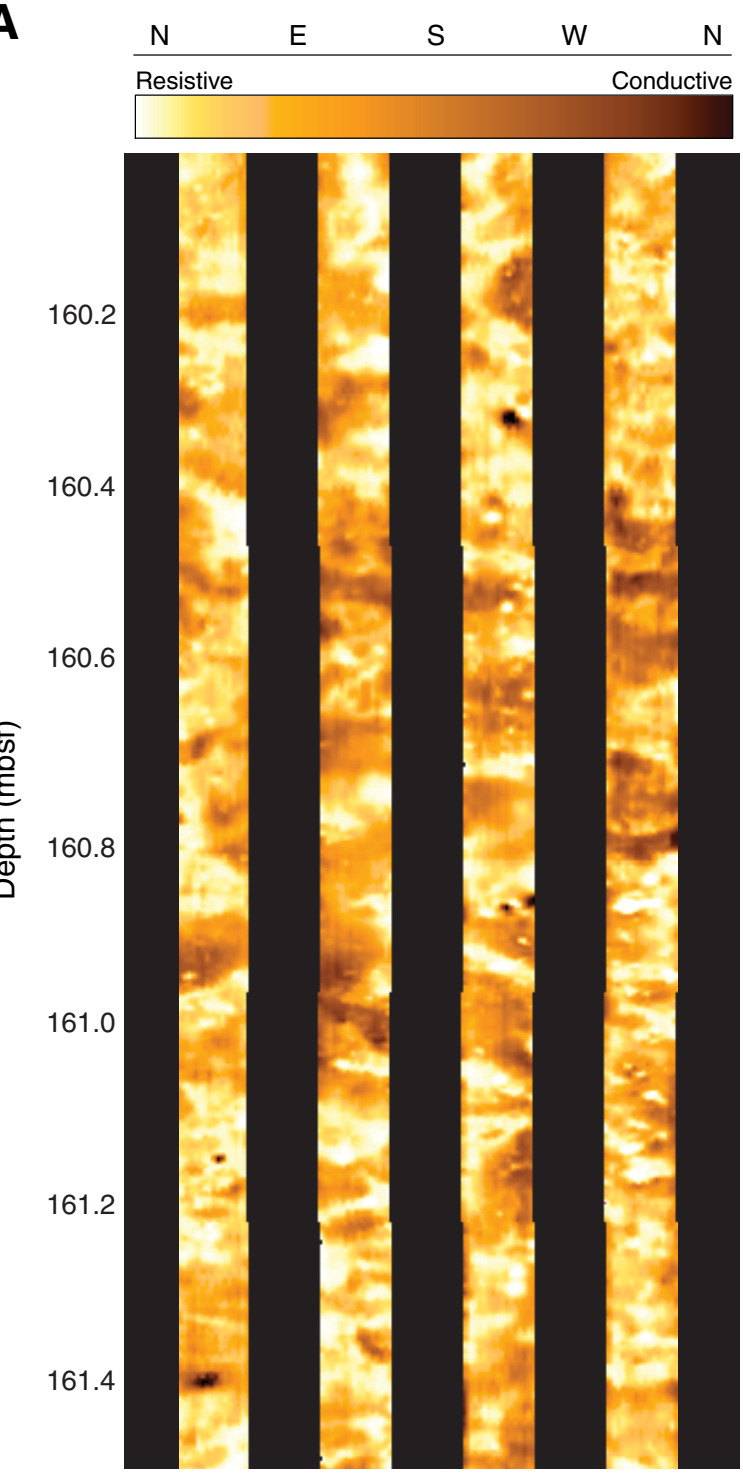

B

\begin{tabular}{ccccr}
$\mathrm{N}$ & $\mathrm{E}$ & $\mathrm{S}$ & $\mathrm{W}$ & $\mathrm{N}$ \\
\hline Resistive & & & & Conductive
\end{tabular}

124.1

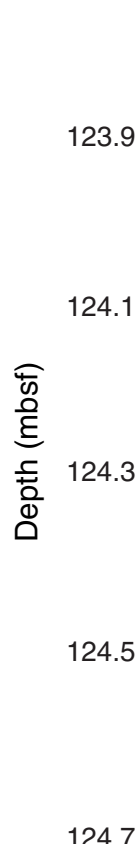

124.5

123.9

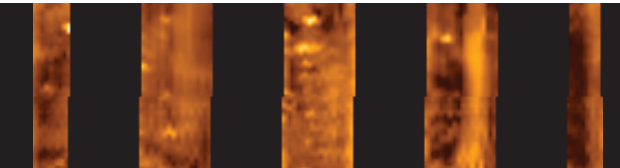

123.7

124.7

124.9
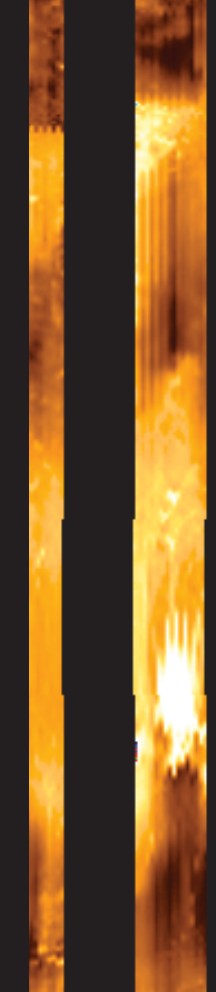

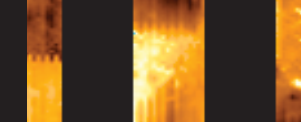

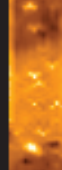


Table T1. Coring summary, Site U1399. (Continued on next page.)

\begin{tabular}{|c|c|c|c|c|c|c|c|c|c|c|}
\hline \multirow{2}{*}{\multicolumn{3}{|c|}{$\begin{array}{l}\text { Hole: } \\
\text { Latitude: }\end{array}$}} & \multicolumn{8}{|c|}{ U1399A } \\
\hline & & & \multicolumn{8}{|c|}{$14^{\circ} 23.2419^{\prime} \mathrm{N}$} \\
\hline \multicolumn{3}{|c|}{ Longitude: } & \multicolumn{8}{|c|}{$61^{\circ} 42.6883^{\prime} \mathrm{W}$} \\
\hline \multicolumn{3}{|c|}{ Water depth $(\mathrm{m})$ : } & \multicolumn{8}{|c|}{2900.8} \\
\hline \multicolumn{3}{|c|}{ Date started (UTC*): } & \multicolumn{8}{|c|}{1815 h 28 March 2012} \\
\hline \multicolumn{3}{|c|}{ Date finished (UTC*): } & $1715 \mathrm{~h}$ & 30 March 2 & 2012 & & & & & \\
\hline Time c & on hole (days) & & 2.0 & & & & & & & \\
\hline Seaflo & or depth DRF & $(m):$ & 2912.4 & & & & & & & \\
\hline Penetr & ration DSF (m & & 274.7 & & & & & & & \\
\hline Cored & interval $(\mathrm{m})$ : & & 274.7 & & & & & & & \\
\hline Recove & ered length ( 1 & & 219.88 & & & & & & & \\
\hline Recove & ery (\%): & & 80 & & & & & & & \\
\hline Total c & cores (no.): & & 36 & & & & & & & \\
\hline Hole: & & & U1399B & & & & & & & \\
\hline Latituc & & & $14^{\circ} 23.3$ & $639^{\prime} \mathrm{N}$ & & & & & & \\
\hline Longit & ude: & & $61^{\circ} 42.5$ & $380^{\prime} \mathrm{W}$ & & & & & & \\
\hline Water & depth (m): & & 2900.22 & & & & & & & \\
\hline Date $s$ & tarted (UTC*) & & $1715 \mathrm{~h}$ & 30 March 2 & 2012 & & & & & \\
\hline Date $\mathrm{fi}$ & inished (UTC* & & $0500 \mathrm{~h}$ & 1 April 2012 & & & & & & \\
\hline Time c & on hole (days) & & 1.5 & & & & & & & \\
\hline Seaflo & or depth DRF & $(m):$ & 2911.8 & & & & & & & \\
\hline Penetr & ation DSF (m & & 183.0 & & & & & & & \\
\hline Cored & interval $(\mathrm{m})$ : & & 180.5 & & & & & & & \\
\hline Recove & ered length ( $r$ & & 183.04 & & & & & & & \\
\hline Recove & ery (\%): & & 101 & & & & & & & \\
\hline Drilled & interval $(\mathrm{m})$ : & & 2.5 & & & & & & & \\
\hline Drilled & interval (no.) & & 1 & & & & & & & \\
\hline Total c & ores (no.): & & 26 & & & & & & & \\
\hline Hole: & & & U1399C & & & & & & & \\
\hline Latituc & & & $14^{\circ} 23.2$ & $593^{\prime} \mathrm{N}$ & & & & & & \\
\hline Longit & ude: & & $61^{\circ} 42.6$ & $665^{\prime} \mathrm{W}$ & & & & & & \\
\hline Water & depth (m): & & 2900.81 & & & & & & & \\
\hline Date $s$ & tarted (UTC*) & & $0500 \mathrm{~h}$ & 1 April 2012 & & & & & & \\
\hline Date $\mathrm{fi}$ & inished (UTC* & & $1015 \mathrm{~h}$ & 4 April 2012 & & & & & & \\
\hline Time c & on hole (days) & & 3.2 & & & & & & & \\
\hline Seaflo & or depth DRF & $(m):$ & 2912.4 & & & & & & & \\
\hline Penetr & ation DSF (m & & 240.0 & & & & & & & \\
\hline Cored & interval $(m)$ : & & 0 & & & & & & & \\
\hline Recove & ered length ( $r$ & & 0 & & & & & & & \\
\hline Recove & ery (\%): & & 0 & & & & & & & \\
\hline Drilled & interval $(m)$ : & & 240 & & & & & & & \\
\hline Drilled & interval (no.) & & 1 & & & & & & & \\
\hline Total c & ores (no.): & & 0 & & & & & & & \\
\hline Core & $\begin{array}{l}\text { Top depth } \\
\text { drilled } \\
\text { DSF (m) }\end{array}$ & $\begin{array}{r}\text { Bottom } \\
\text { dri } \\
\text { DSF }\end{array}$ & $\begin{array}{l}m \text { depth } \\
\text { rilled } \\
\text { if }(m)\end{array}$ & $\begin{array}{l}\text { Advanced } \\
(\mathrm{m})\end{array}$ & $\begin{array}{l}\text { Recovered } \\
\text { length } \\
(\mathrm{m})\end{array}$ & $\begin{array}{l}\text { Curated } \\
\text { length } \\
(\mathrm{m})\end{array}$ & $\begin{array}{l}\text { Top depth } \\
\text { cored } \\
\text { CSF }(m)\end{array}$ & $\begin{array}{l}\text { Bottom depth } \\
\text { recovered } \\
\text { CSF }(m)\end{array}$ & $\begin{array}{l}\text { Recovery } \\
\text { (\%) }\end{array}$ & $\begin{array}{l}\text { Time on deck } \\
\left(\text { UTC }^{\star}\right)\end{array}$ \\
\hline 340-U13 & 99A- & & & & & & & & & \\
\hline $1 \mathrm{H}$ & 0.0 & & 5.1 & 5.1 & 5.10 & 5.10 & 0.0 & 5.10 & 100 & $3 / 29 / 12$ 06:05 \\
\hline $2 \mathrm{H}$ & 5.1 & & 4.6 & 9.5 & 10.09 & 10.09 & 5.1 & 15.19 & 106 & $3 / 29 / 12$ 07:00 \\
\hline $3 \mathrm{H}$ & 14.6 & & 24.1 & 9.5 & 9.72 & 9.72 & 14.6 & 24.32 & 102 & $3 / 29 / 12$ 08:20 \\
\hline $4 \mathrm{H}$ & 24.1 & & 33.6 & 9.5 & 10.08 & 10.08 & 24.1 & 34.18 & 106 & $3 / 29 / 1209: 20$ \\
\hline $5 \mathrm{H}$ & 33.6 & & 43.1 & 9.5 & 10.12 & 10.12 & 33.6 & 43.72 & 107 & $3 / 29 / 12$ 10:25 \\
\hline $6 \mathrm{H}$ & 43.1 & & 52.6 & 9.5 & 9.84 & 9.84 & 43.1 & 52.94 & 104 & $3 / 29 / 1211: 25$ \\
\hline $7 \mathrm{H}$ & 52.6 & & 52.1 & 9.5 & 9.62 & 9.62 & 52.6 & 62.22 & 101 & $3 / 29 / 12$ 12:10 \\
\hline $8 \mathrm{H}$ & 62.1 & & 70.8 & 8.7 & 8.76 & 8.76 & 62.1 & 70.86 & 101 & $3 / 29 / 1213: 00$ \\
\hline $9 \mathrm{H}$ & 70.8 & & 30.3 & 9.5 & 9.95 & 9.95 & 70.8 & 80.75 & 105 & $3 / 29 / 1213: 55$ \\
\hline $10 \mathrm{H}$ & 80.3 & & 39.8 & 9.5 & 9.95 & 9.95 & 80.3 & 90.25 & 105 & $3 / 29 / 12$ 14:40 \\
\hline $11 \mathrm{H}$ & 89.8 & & 92.1 & 2.3 & 2.37 & 2.37 & 89.8 & 92.17 & 103 & $3 / 29 / 12$ 15:30 \\
\hline $12 \mathrm{H}$ & 92.1 & & 95.1 & 3.0 & 3.04 & 3.04 & 92.1 & 95.14 & 101 & $3 / 29 / 12$ 16:45 \\
\hline $13 \mathrm{H}$ & 95.1 & & 2.9 & 7.8 & 7.89 & 7.89 & 95.1 & 102.99 & 101 & $3 / 29 / 1218: 35$ \\
\hline $14 \mathrm{H}$ & 102.9 & & 2.0 & 9.1 & 9.19 & 9.19 & 102.9 & 112.09 & 101 & $3 / 29 / 12$ 20:10 \\
\hline $15 \mathrm{H}$ & 112.0 & & 21.5 & 9.5 & 9.96 & 9.96 & 112.0 & 121.96 & 105 & $3 / 29 / 12$ 21:35 \\
\hline $16 \mathrm{H}$ & 121.5 & & 31.0 & 9.5 & 10.04 & 10.04 & 121.5 & 131.54 & 106 & $3 / 29 / 12$ 22:25 \\
\hline $17 \mathrm{H}$ & 131.0 & & 40.5 & 9.5 & 10.02 & 10.02 & 131.0 & 141.02 & 105 & $3 / 29 / 1223: 10$ \\
\hline $18 \mathrm{H}$ & 140.5 & & 50.0 & 9.5 & 9.86 & 9.86 & 140.5 & 150.36 & 104 & $3 / 30 / 1200: 05$ \\
\hline $19 \mathrm{H}$ & 150.0 & & 53.4 & 3.4 & 0.31 & 0.31 & 150.0 & 150.31 & 9 & $3 / 30 / 1200: 55$ \\
\hline $20 \mathrm{H}$ & 153.4 & & 50.6 & 7.2 & 7.25 & 7.25 & 153.4 & 160.65 & 101 & $3 / 30 / 1201: 55$ \\
\hline $21 \mathrm{H}$ & 160.6 & & 54.2 & 3.6 & 3.66 & 3.66 & 160.6 & 164.26 & 102 & $3 / 30 / 12$ 03:15 \\
\hline $22 \mathrm{H}$ & 164.2 & & 57.2 & 3.0 & 3.07 & 3.07 & 164.2 & 167.27 & 102 & $3 / 30 / 12$ 04:05 \\
\hline
\end{tabular}


Table T1 (continued).

\begin{tabular}{|c|c|c|c|c|c|c|c|c|c|}
\hline Core & $\begin{array}{l}\text { Top depth } \\
\text { drilled } \\
\text { DSF }(m)\end{array}$ & $\begin{array}{c}\text { Bottom depth } \\
\text { drilled } \\
\text { DSF }(m)\end{array}$ & $\begin{array}{c}\text { Advanced } \\
\text { (m) }\end{array}$ & $\begin{array}{l}\text { Recovered } \\
\text { length } \\
(\mathrm{m})\end{array}$ & $\begin{array}{l}\text { Curated } \\
\text { length } \\
\text { (m) }\end{array}$ & $\begin{array}{l}\text { Top depth } \\
\text { cored } \\
\text { CSF }(m)\end{array}$ & $\begin{array}{l}\text { Bottom depth } \\
\text { recovered } \\
\text { CSF }(m)\end{array}$ & $\begin{array}{l}\text { Recovery } \\
\text { (\%) }\end{array}$ & $\begin{array}{l}\text { Time on deck } \\
\left(\text { UTC }^{*}\right)\end{array}$ \\
\hline $23 \mathrm{H}$ & 167.2 & 175.4 & 8.2 & 8.27 & 8.27 & 167.2 & 175.47 & 101 & $3 / 30 / 1206: 30$ \\
\hline $24 \mathrm{H}$ & 175.4 & 184.5 & 9.1 & 9.10 & 9.10 & 175.4 & 184.50 & 100 & $3 / 30 / 1207: 30$ \\
\hline $25 \mathrm{H}$ & 184.5 & 191.7 & 7.2 & 7.28 & 7.28 & 184.5 & 191.78 & 101 & $3 / 30 / 12$ 08:25 \\
\hline $26 \mathrm{H}$ & 191.7 & 197.7 & 6.0 & 6.04 & 6.04 & 191.7 & 197.74 & 101 & $3 / 30 / 1209: 45$ \\
\hline $27 \mathrm{H}$ & 197.7 & 203.9 & 6.2 & 6.20 & 6.20 & 197.7 & 203.90 & 100 & 3/30/12 11:05 \\
\hline $28 \mathrm{H}$ & 203.9 & 205.5 & 1.6 & 1.63 & 1.63 & 203.9 & 205.53 & 102 & $3 / 30 / 1211: 55$ \\
\hline $29 \mathrm{H}$ & 205.5 & 207.5 & 2.0 & 2.04 & 2.04 & 205.5 & 207.54 & 102 & $3 / 30 / 1212: 50$ \\
\hline $30 x$ & 207.5 & 217.1 & 9.6 & 2.04 & 2.04 & 207.5 & 209.54 & 21 & $3 / 30 / 1214: 40$ \\
\hline $31 x$ & 217.1 & 226.7 & 9.6 & 1.12 & 2.04 & 217.1 & 218.22 & 12 & $3 / 30 / 12$ 15:50 \\
\hline $32 x$ & 226.7 & 236.3 & 9.6 & 2.04 & 2.04 & 226.7 & 228.74 & 21 & $3 / 30 / 12$ 17:10 \\
\hline $33 x$ & 236.3 & 245.9 & 9.6 & 1.49 & 2.04 & 236.3 & 237.79 & 16 & $3 / 30 / 1218: 30$ \\
\hline $34 \mathrm{X}$ & 245.9 & 255.5 & 9.6 & 1.12 & 2.04 & 245.9 & 247.02 & 12 & $3 / 30 / 12$ 19:55 \\
\hline $35 x$ & 255.5 & 265.1 & 9.6 & 0.98 & 0.98 & 255.5 & 256.48 & 10 & $3 / 30 / 1221: 25$ \\
\hline $36 x$ & 265.1 & 274.7 & 9.6 & 4.72 & 4.72 & 265.1 & 269.82 & 49 & $3 / 30 / 1223: 05$ \\
\hline \multicolumn{10}{|c|}{ 340-U1399B- } \\
\hline $1 \mathrm{H}$ & 0.0 & 5.7 & 5.7 & 5.78 & 5.78 & 0.0 & 5.78 & 101 & $3 / 31 / 1203: 25$ \\
\hline $2 \mathrm{H}$ & 5.7 & 15.2 & 9.5 & 9.85 & 9.85 & 5.7 & 15.55 & 104 & $3 / 31 / 1204: 25$ \\
\hline $3 \mathrm{H}$ & 15.2 & 24.7 & 9.5 & 9.94 & 9.94 & 15.2 & 25.14 & 105 & $3 / 31 / 12$ 05:30 \\
\hline $4 \mathrm{H}$ & 24.7 & 34.2 & 9.5 & 10.04 & 10.04 & 24.7 & 34.74 & 106 & $3 / 31 / 1206: 15$ \\
\hline $5 \mathrm{H}$ & 34.2 & 43.7 & 9.5 & 9.96 & 9.96 & 34.2 & 44.16 & 105 & $3 / 31 / 12$ 07:00 \\
\hline $6 \mathrm{H}$ & 43.7 & 53.2 & 9.5 & 9.86 & 9.86 & 43.7 & 53.56 & 104 & $3 / 31 / 12$ 08:05 \\
\hline $7 \mathrm{H}$ & 53.2 & 62.7 & 9.5 & 8.16 & 8.16 & 53.2 & 61.36 & 86 & $3 / 31 / 1208: 45$ \\
\hline $8 \mathrm{H}$ & 62.7 & 71.9 & 9.2 & 9.26 & 9.26 & 62.7 & 71.96 & 101 & $3 / 31 / 1209: 45$ \\
\hline $9 \mathrm{H}$ & 71.9 & 81.2 & 9.3 & 9.32 & 9.32 & 71.9 & 81.22 & 100 & $3 / 31 / 1210: 45$ \\
\hline $10 \mathrm{H}$ & 81.2 & 89.8 & 8.6 & 8.67 & 8.67 & 81.2 & 89.87 & 101 & $3 / 31 / 1211: 40$ \\
\hline $11 \mathrm{H}$ & 89.8 & 94.3 & 4.5 & 4.58 & 4.58 & 89.8 & 94.38 & 102 & $3 / 31 / 1212: 35$ \\
\hline $12 \mathrm{H}$ & 94.3 & 102.7 & 8.4 & 8.44 & 8.44 & 94.3 & 102.74 & 100 & $3 / 31 / 1213: 35$ \\
\hline $13 \mathrm{H}$ & 102.7 & 112.2 & 9.5 & 9.84 & 9.84 & 102.7 & 112.54 & 104 & $3 / 31 / 1214: 35$ \\
\hline $14 \mathrm{H}$ & 112.2 & 114.7 & 2.5 & 2.50 & 2.50 & 112.2 & 114.70 & 100 & $3 / 31 / 1215: 20$ \\
\hline $15 \mathrm{H}$ & 114.7 & 124.2 & 9.5 & 10.02 & 10.02 & 114.7 & 124.72 & 105 & $3 / 31 / 1216: 25$ \\
\hline $16 \mathrm{H}$ & 124.2 & 126.7 & 2.5 & 2.52 & 2.52 & 124.2 & 126.72 & 101 & $3 / 31 / 12 \quad 17: 05$ \\
\hline $17 \mathrm{H}$ & 126.7 & 128.9 & 2.2 & 2.28 & 2.28 & 126.7 & 128.98 & 104 & $3 / 31 / 1218: 05$ \\
\hline $18 \mathrm{H}$ & 128.9 & 133.6 & 4.7 & 4.72 & 4.72 & 128.9 & 133.62 & 100 & $3 / 31 / 1218: 55$ \\
\hline $19 \mathrm{H}$ & 133.6 & 143.1 & 9.5 & 9.59 & 9.59 & 133.6 & 143.19 & 101 & $3 / 31 / 1219: 50$ \\
\hline 201 & \multicolumn{8}{|c|}{ 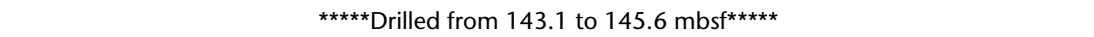 } & $3 / 31 / 1220: 50$ \\
\hline $21 \mathrm{H}$ & 145.6 & 149.5 & 3.9 & 3.92 & 3.92 & 145.6 & 149.52 & 101 & $3 / 31 / 1222: 05$ \\
\hline $22 \mathrm{H}$ & 149.5 & 157.8 & 8.3 & 8.37 & 8.37 & 149.5 & 157.87 & 101 & 3/31/12 23:05 \\
\hline $23 \mathrm{H}$ & 157.8 & 159.3 & 1.5 & 1.51 & 8.37 & 157.8 & 159.31 & 101 & 4/1/12 23:55 \\
\hline $24 \mathrm{H}$ & 159.3 & 166.4 & 7.1 & 7.19 & 7.19 & 159.3 & 166.49 & 101 & 4/1/12 01:15 \\
\hline $25 \mathrm{H}$ & 166.4 & 173.3 & 6.9 & 6.91 & 7.19 & 166.4 & 173.31 & 100 & 4/1/12 02:40 \\
\hline $26 \mathrm{H}$ & 173.3 & 173.8 & 0.5 & 0.55 & 0.55 & 173.3 & 173.85 & 110 & 4/1/12 03:40 \\
\hline $27 \mathrm{H}$ & 173.8 & 183.0 & 9.2 & 9.26 & 9.26 & 173.8 & 183.06 & 101 & 4/1/12 04:30 \\
\hline \multirow{2}{*}{\multicolumn{9}{|c|}{$\begin{array}{l}\text { 340-U1399C- } \\
11\end{array}$}} & \multirow{3}{*}{$4 / 2 / 1206: 00$} \\
\hline & & & & & & & & & \\
\hline & & Totals: & 697.7 & 402.92 & 426.37 & & & & \\
\hline
\end{tabular}

* = ship local time was Universal Time Coordinated (UTC) $-4 \mathrm{~h} . \mathrm{DRF}=$ drilling depth below rig floor, DSF $=$ drilling depth below seafloor, CSF $=$ core depth below seafloor. $\mathrm{H}=$ advanced piston corer, $\mathrm{X}=$ extended core barrel. 
Table T2. Solid-phase geochemistry, Site U1399.

\begin{tabular}{|c|c|c|c|c|c|c|c|}
\hline \multirow{2}{*}{$\begin{array}{l}\text { Core, } \\
\text { section }\end{array}$} & \multicolumn{2}{|c|}{ Depth (mbsf) } & \multicolumn{4}{|c|}{ Carbon (wt\%) } & \multirow{2}{*}{$\begin{array}{c}\text { Nitrogen } \\
(w t \%)\end{array}$} \\
\hline & Top & Bottom & $\mathrm{CaCO}_{3}$ & Inorganic & Total & Organic & \\
\hline \multicolumn{8}{|c|}{ 340-U1399A- } \\
\hline $1 \mathrm{H}-1$ & 0.73 & 0.74 & 30.25 & 3.63 & 4.26 & 0.63 & 0.04 \\
\hline $1 \mathrm{H}-2$ & 1.59 & 1.60 & 2.19 & 0.26 & 0.33 & 0.07 & $\mathrm{BD}$ \\
\hline $2 \mathrm{H}-4$ & 10.72 & 10.73 & 19.94 & 2.39 & 3.30 & 0.91 & 0.05 \\
\hline $2 \mathrm{H}-6$ & 12.89 & 12.90 & 32.40 & 3.88 & 4.72 & 0.84 & 0.03 \\
\hline $3 \mathrm{H}-1$ & 15.29 & 15.30 & 4.20 & 0.50 & 0.56 & 0.06 & BD \\
\hline $3 \mathrm{H}-3$ & 18.06 & 18.07 & 29.38 & 3.52 & 4.21 & 0.69 & 0.04 \\
\hline $4 \mathrm{H}-2$ & 26.45 & 26.46 & 7.34 & 0.88 & 1.23 & 0.35 & 0.02 \\
\hline $4 \mathrm{H}-4$ & 29.65 & 29.66 & 20.43 & 2.45 & 3.13 & 0.68 & 0.05 \\
\hline $5 \mathrm{H}-3$ & 36.70 & 36.71 & 21.58 & 2.59 & 3.45 & 0.86 & 0.06 \\
\hline $5 \mathrm{H}-5$ & 40.94 & 40.95 & 9.21 & 1.10 & 1.83 & 0.73 & 0.07 \\
\hline $6 \mathrm{H}-1$ & 43.79 & 43.80 & 25.65 & 3.08 & 3.83 & 0.75 & 0.05 \\
\hline $6 \mathrm{H}-6$ & 51.63 & 51.64 & 16.70 & 2.00 & 2.70 & 0.70 & 0.05 \\
\hline $7 \mathrm{H}-1$ & 53.61 & 53.62 & 34.12 & 4.09 & 5.09 & 1.00 & 0.06 \\
\hline $7 \mathrm{H}-5$ & 59.74 & 59.75 & 16.93 & 2.03 & 2.59 & 0.56 & 0.04 \\
\hline $8 \mathrm{H}-1$ & 62.54 & 62.55 & 26.89 & 3.22 & 3.92 & 0.70 & 0.04 \\
\hline $9 \mathrm{H}-4$ & 76.61 & 76.62 & 14.35 & 1.72 & 2.33 & 0.61 & 0.04 \\
\hline $9 \mathrm{H}-7$ & 79.96 & 79.97 & 10.91 & 1.31 & 2.17 & 0.86 & 0.07 \\
\hline $10 \mathrm{H}-2$ & 82.82 & 82.83 & 13.48 & 1.62 & 2.08 & 0.46 & 0.04 \\
\hline $10 \mathrm{H}-5$ & 86.85 & 86.86 & 2.85 & 0.34 & 1.11 & 0.77 & 0.07 \\
\hline $11 \mathrm{H}-1$ & 90.23 & 90.24 & 6.54 & 0.78 & 1.00 & 0.22 & $\mathrm{BD}$ \\
\hline $12 \mathrm{H}-3$ & 94.29 & 94.30 & 1.52 & 0.18 & & & \\
\hline $13 \mathrm{H}-1$ & 95.70 & 95.71 & 22.96 & 2.75 & 3.23 & 0.48 & 0.03 \\
\hline $14 \mathrm{H}-1$ & 103.42 & 103.43 & 26.37 & 3.16 & 3.91 & 0.75 & 0.05 \\
\hline $14 \mathrm{H}-2$ & 104.99 & 105.00 & & & 1.03 & & BD \\
\hline $15 \mathrm{H}-2$ & 114.09 & 114.10 & 34.16 & 4.10 & 5.00 & 0.90 & 0.05 \\
\hline $16 \mathrm{H}-4$ & 126.40 & 126.41 & 13.52 & 1.62 & 2.00 & 0.38 & 0.03 \\
\hline $17 \mathrm{H}-3$ & 134.91 & 134.92 & 10.65 & 1.28 & 1.48 & 0.20 & 0.01 \\
\hline $17 \mathrm{H}-7$ & 140.02 & 140.03 & 23.91 & 2.87 & 3.39 & 0.52 & 0.05 \\
\hline $18 \mathrm{H}-1$ & 141.05 & 141.06 & 18.45 & 2.21 & 2.70 & 0.49 & 0.04 \\
\hline $20 \mathrm{H}-1$ & 154.40 & 154.41 & 12.78 & 1.53 & 2.02 & 0.49 & 0.04 \\
\hline $20 \mathrm{H}-4$ & 158.29 & 158.30 & 20.02 & 2.40 & 2.99 & 0.59 & 0.03 \\
\hline $23 \mathrm{H}-1$ & 167.82 & 167.83 & 19.19 & 2.30 & 2.81 & 0.51 & 0.03 \\
\hline $23 \mathrm{H}-5$ & 174.45 & 174.46 & 22.41 & 2.69 & 3.15 & 0.46 & 0.04 \\
\hline $24 \mathrm{H}-1$ & 175.78 & 175.79 & 16.88 & 2.02 & 2.59 & 0.57 & 0.04 \\
\hline $25 \mathrm{H}-1$ & 185.20 & 185.21 & 21.09 & 2.53 & 3.12 & 0.59 & 0.06 \\
\hline $26 \mathrm{H}-1$ & 191.85 & 191.86 & 32.21 & 3.86 & 4.48 & 0.62 & 0.05 \\
\hline $26 \mathrm{H}-3$ & 195.54 & 195.55 & 1.74 & 0.21 & 0.27 & 0.06 & 0.01 \\
\hline $27 \mathrm{H}-1$ & 198.48 & 198.49 & 19.64 & 2.36 & 2.90 & 0.54 & 0.05 \\
\hline $27 \mathrm{H}-4$ & 202.56 & 202.57 & 25.02 & 3.00 & 3.67 & 0.67 & 0.05 \\
\hline $28 \mathrm{H}-2$ & 205.06 & 205.07 & 20.74 & 2.49 & 2.93 & 0.44 & 0.05 \\
\hline $29 \mathrm{H}-1$ & 206.22 & 206.23 & 28.86 & 3.46 & 3.92 & 0.46 & 0.03 \\
\hline $31 X-1$ & 217.87 & 217.88 & 30.50 & 3.66 & 4.15 & 0.49 & 0.05 \\
\hline $33 X-1$ & 237.25 & 237.26 & 25.15 & 3.02 & 3.59 & 0.57 & 0.04 \\
\hline $36 X-3$ & 269.08 & 269.09 & 22.10 & 2.65 & 3.27 & 0.62 & 0.07 \\
\hline $36 X-3$ & 269.08 & 269.09 & & & 3.30 & & 0.07 \\
\hline \multicolumn{8}{|c|}{ 340-U1399B- } \\
\hline $19 \mathrm{H}-3$ & 137.04 & 137.05 & 11.40 & 1.37 & 2.07 & 0.70 & 0.07 \\
\hline $24 \mathrm{H}-2$ & 161.53 & 161.54 & 12.12 & 1.45 & 1.71 & 0.26 & 0.01 \\
\hline
\end{tabular}

$\mathrm{BD}=$ below detection limit. 
Table T3. Composition of interstitial pore water, Hole U1399B.

\begin{tabular}{|c|c|c|c|c|c|c|c|c|c|c|c|c|c|c|c|c|c|c|}
\hline \multirow{2}{*}{$\begin{array}{c}\text { Core, } \\
\text { section }\end{array}$} & \multicolumn{2}{|c|}{ Depth (mbsf) } & \multirow{2}{*}{$\begin{array}{l}\text { Alkalinity } \\
(\mathrm{mM})\end{array}$} & \multirow[b]{2}{*}{$\mathrm{pH}$} & \multirow{2}{*}{$\begin{array}{c}\mathrm{Cl} \\
(\mathrm{mM})\end{array}$} & \multirow[b]{2}{*}{ \pm} & \multirow[b]{2}{*}{ Salinity } & \multirow{2}{*}{$\begin{array}{c}\mathrm{NH}_{4} \\
(\mathrm{mM})\end{array}$} & \multirow{2}{*}{$\begin{array}{c}\mathrm{Na} \\
(\mathrm{mM})\end{array}$} & \multirow[b]{2}{*}{ \pm} & \multirow{2}{*}{$\begin{array}{c}\mathrm{Mg} \\
(\mathrm{mM})\end{array}$} & \multirow[b]{2}{*}{ \pm} & \multirow{2}{*}{$\begin{array}{c}\mathrm{K} \\
(\mathrm{mM})\end{array}$} & \multirow[b]{2}{*}{ \pm} & \multirow{2}{*}{$\begin{array}{c}\mathrm{Ca} \\
(\mathrm{mM})\end{array}$} & \multirow[b]{2}{*}{ \pm} & \multirow{2}{*}{$\underset{(\mathrm{mM})}{\Sigma \mathrm{S}}$} & \multirow[b]{2}{*}{ \pm} \\
\hline & Top & Bottom & & & & & & & & & & & & & & & & \\
\hline \multicolumn{19}{|c|}{ 340-U1399B- } \\
\hline $1 H-2$ & 2.90 & 3.00 & 4.17 & 7.99 & 556.8 & & 37 & 0.02 & 467 & 22 & 53.0 & 3.3 & 10.7 & 0.5 & 10.58 & 0.60 & 28.4 & 2.2 \\
\hline $2 \mathrm{H}-3$ & 10.10 & 10.20 & 3.03 & 7.38 & 557.3 & & 37 & 0.02 & 472 & 3 & 52.8 & 0.5 & 11.1 & 0.2 & 10.35 & 0.07 & 28.2 & 0.2 \\
\hline $3 \mathrm{H}-3$ & 19.62 & 19.72 & 4.27 & 7.35 & 565.8 & & 37 & 0.22 & 473 & 3 & 52.2 & 0.4 & 10.8 & 0.2 & 9.56 & 0.05 & 26.7 & 0.3 \\
\hline $3 \mathrm{H}-5$ & 22.60 & 22.70 & 5.08 & 7.72 & 564.4 & & 37 & 0.31 & & & & & & & & & & \\
\hline $4 \mathrm{H}-2$ & 27.60 & 27.70 & 5.91 & 7.54 & 562.7 & & 37 & 0.45 & 477 & 1 & 52.6 & 0.4 & 10.2 & 0.2 & 8.21 & 0.05 & 24.1 & 0.2 \\
\hline $4 \mathrm{H}-4$ & 30.60 & 30.70 & 6.80 & 8.00 & 567.2 & & 37 & 0.52 & 477 & 2 & 52.3 & 0.4 & 10.2 & 0.1 & 7.79 & 0.06 & 23.5 & 0.2 \\
\hline $5 \mathrm{H}-3$ & 38.60 & 38.70 & 7.18 & 7.55 & 569.0 & & 37 & 0.65 & 476 & 4 & 52.0 & 0.6 & 10.6 & 0.2 & 6.89 & 0.07 & 21.9 & 0.2 \\
\hline $5 \mathrm{H}-5$ & 41.60 & 41.70 & 7.56 & 7.51 & 565.2 & & 37 & 0.69 & 479 & 2 & 51.6 & 0.4 & 10.7 & 0.1 & 6.54 & 0.05 & 21.5 & 0.3 \\
\hline $6 \mathrm{H}-2$ & 46.50 & 46.60 & 8.07 & 7.58 & 567.3 & & 37 & 0.72 & 475 & 4 & 50.9 & 0.4 & 10.1 & 0.2 & 5.87 & 0.06 & 20.2 & 0.2 \\
\hline $6 \mathrm{H}-4$ & 49.45 & 49.55 & 8.28 & 7.55 & 567.1 & & 37 & 0.76 & 477 & 1 & 50.9 & 0.6 & 10.4 & 0.0 & 5.76 & 0.03 & 19.4 & 0.3 \\
\hline $8 \mathrm{H}-1$ & 64.12 & 64.22 & 9.35 & 7.68 & 568.8 & & 37 & 0.83 & 481 & 3 & 50.9 & 0.5 & 10.0 & 0.1 & 5.20 & 0.05 & 17.8 & 0.2 \\
\hline $8 \mathrm{H}-3$ & 67.07 & 67.17 & 9.38 & 7.63 & 568.3 & 2.4 & 37 & 0.85 & 478 & 5 & 50.7 & 0.6 & 10.0 & 0.4 & 4.88 & 0.07 & 16.9 & 0.3 \\
\hline $9 \mathrm{H}-3$ & 76.32 & 76.42 & 9.62 & 7.59 & 567.0 & & 37 & 0.86 & 477 & 2 & 50.2 & 0.4 & 9.8 & 0.2 & 4.44 & 0.06 & 15.5 & 0.3 \\
\hline $12 \mathrm{H}-1$ & 95.72 & 95.82 & 9.69 & 7.61 & 568.6 & & 37 & 0.89 & 482 & 2 & 49.7 & 0.4 & 9.8 & 0.1 & 4.18 & 0.06 & 14.0 & 0.3 \\
\hline $13 \mathrm{H}-3$ & 107.10 & 107.20 & 10.27 & 7.68 & 569.2 & & 37 & 0.93 & 478 & 1 & 49.4 & 0.3 & 9.8 & 0.2 & 4.24 & 0.05 & 13.3 & 0.2 \\
\hline $15 \mathrm{H}-5$ & 122.13 & 122.24 & 10.67 & 7.63 & 566.2 & & 37 & 0.95 & 482 & 1 & 48.6 & 0.6 & 9.4 & 0.2 & 4.24 & 0.05 & 12.1 & 0.2 \\
\hline $18 \mathrm{H}-2$ & 131.83 & 131.93 & 11.48 & 7.61 & 574.4 & & 37 & 1.01 & 485 & 6 & 48.3 & 0.1 & 9.4 & 0.0 & 4.41 & 0.02 & 10.8 & 0.2 \\
\hline $24 \mathrm{H}-1$ & 160.70 & 160.80 & 11.99 & 7.65 & 575.1 & & 36 & 1.10 & 482 & 6 & 47.0 & 0.0 & 9.1 & 0.0 & 3.71 & 0.03 & 7.9 & 0.0 \\
\hline $25 \mathrm{H}-1$ & 167.80 & 167.90 & 11.45 & 7.59 & 576.9 & & 36 & 1.04 & 484 & 7 & 47.0 & 0.2 & 8.8 & 0.0 & 3.42 & 0.03 & 7.2 & 0.1 \\
\hline
\end{tabular}

Uncertainties for $\mathrm{Cl}$ represent $\pm 1 \sigma$ based on repeat analyses. Shaded samples represent average values for $\mathrm{Na}, \mathrm{Mg}, \mathrm{K}, \mathrm{Ca}$, and $\Sigma \mathrm{S}$ (total sulfur) from duplicate analyses from separate runs. Samples in italics represent averages from within-run duplicates. 
Table T4. Correlation point picks and depth shifts, Hole U1399B.

\begin{tabular}{|c|c|c|}
\hline $\begin{array}{l}\text { Original } \\
\text { depth } \\
\text { (mbsf) }\end{array}$ & $\begin{array}{c}\text { Corrected } \\
\text { depth } \\
\text { (mbsf) }\end{array}$ & $\begin{array}{l}\text { Difference } \\
\qquad(\mathrm{m})\end{array}$ \\
\hline 2.533 & 2.056 & 0.476 \\
\hline 4.541 & 3.989 & 0.551 \\
\hline 6.346 & 5.347 & 0.999 \\
\hline 8.705 & 7.399 & 1.306 \\
\hline 9.502 & 8.274 & 1.228 \\
\hline 9.766 & 8.531 & 1.234 \\
\hline 10.762 & 9.972 & 0.790 \\
\hline 12.419 & 11.328 & 1.091 \\
\hline 13.227 & 11.846 & 1.381 \\
\hline 13.500 & 12.008 & 1.492 \\
\hline 14.459 & 13.729 & 0.730 \\
\hline 14.968 & 14.722 & 0.246 \\
\hline 16.324 & 16.768 & -0.445 \\
\hline 19.593 & 19.537 & 0.056 \\
\hline 21.227 & 21.640 & -0.413 \\
\hline 22.210 & 22.209 & 0.002 \\
\hline 22.706 & 22.801 & -0.095 \\
\hline 23.998 & 25.711 & -1.713 \\
\hline 25.028 & 27.225 & -2.197 \\
\hline 26.811 & 31.020 & -4.209 \\
\hline 28.063 & 33.001 & -4.938 \\
\hline 34.474 & 45.534 & -11.061 \\
\hline 37.148 & 47.166 & -10.018 \\
\hline 37.930 & 48.201 & -10.271 \\
\hline 38.335 & 48.639 & -10.304 \\
\hline 39.782 & 49.742 & -9.960 \\
\hline 40.514 & 50.707 & -10.194 \\
\hline 40.822 & 51.114 & -10.293 \\
\hline 45.609 & 56.392 & -10.783 \\
\hline 48.183 & 60.335 & -12.151 \\
\hline 52.295 & 70.512 & -18.217 \\
\hline 54.607 & 70.939 & -16.332 \\
\hline 59.982 & 73.851 & -13.869 \\
\hline 63.772 & 75.882 & -12.110 \\
\hline 68.484 & 77.062 & -8.579 \\
\hline 72.016 & 78.467 & -6.451 \\
\hline 74.826 & 82.543 & -7.717 \\
\hline 77.289 & 87.517 & -10.228 \\
\hline 79.667 & 91.380 & -11.712 \\
\hline 80.773 & 94.455 & -13.682 \\
\hline 94.007 & 103.008 & -9.001 \\
\hline 96.286 & 103.958 & -7.672 \\
\hline 102.363 & 111.611 & -9.248 \\
\hline 105.686 & 114.402 & -8.716 \\
\hline 108.629 & 119.475 & -10.846 \\
\hline 109.641 & 120.047 & -10.406 \\
\hline 115.159 & 122.680 & -7.522 \\
\hline 121.017 & 137.752 & -16.734 \\
\hline 123.792 & 139.064 & -15.273 \\
\hline 126.261 & 142.089 & -15.828 \\
\hline 131.354 & 147.589 & -16.235 \\
\hline 136.210 & 154.084 & -17.874 \\
\hline 147.363 & 163.204 & -15.841 \\
\hline 148.437 & 164.497 & -16.060 \\
\hline 152.384 & 168.139 & -15.756 \\
\hline 157.439 & 170.663 & -13.225 \\
\hline 160.911 & 172.916 & -12.005 \\
\hline 161.586 & 173.892 & -12.306 \\
\hline 162.736 & 175.159 & -12.423 \\
\hline 165.992 & 177.666 & -11.674 \\
\hline 170.697 & 183.752 & -13.056 \\
\hline 171.989 & 184.158 & -12.170 \\
\hline 175.516 & 186.217 & -10.701 \\
\hline 178.452 & 188.908 & -10.457 \\
\hline 182.215 & 191.476 & -9.262 \\
\hline
\end{tabular}


Table T5. Samples measured for paleomagnetism, Site U1399.

\begin{tabular}{|c|c|c|}
\hline Core & $\begin{array}{l}\text { Measured } \\
\quad(\mathrm{mT})\end{array}$ & $\begin{array}{c}\text { APC } \\
\text { core barrel }\end{array}$ \\
\hline \multicolumn{3}{|c|}{ 340-U1399A- } \\
\hline $1 \mathrm{H}$ & 0,20 & Nonmagnetic \\
\hline $2 \mathrm{H}$ & 0,20 & Nonmagnetic \\
\hline $3 \mathrm{H}$ & 0,20 & Nonmagnetic \\
\hline $4 \mathrm{H}$ & 0,20 & Nonmagnetic \\
\hline $5 \mathrm{H}$ & 0,20 & Nonmagnetic \\
\hline $6 \mathrm{H}$ & 0,20 & Nonmagnetic \\
\hline $7 \mathrm{H}$ & 0,20 & Nonmagnetic \\
\hline $8 \mathrm{H}$ & 0,20 & Nonmagnetic \\
\hline $9 \mathrm{H}$ & 0,20 & Nonmagnetic \\
\hline $10 \mathrm{H}$ & 0,20 & Nonmagnetic \\
\hline $11 \mathrm{H}$ & 0,20 & Nonmagnetic \\
\hline $12 \mathrm{H}$ & 0,20 & Nonmagnetic \\
\hline $13 \mathrm{H}$ & 0,20 & Standard \\
\hline $14 \mathrm{H}$ & 0,20 & Standard \\
\hline $15 \mathrm{H}$ & 0,20 & Standard \\
\hline $16 \mathrm{H}$ & 0,20 & Standard \\
\hline $17 \mathrm{H}$ & 0,20 & Standard \\
\hline $18 \mathrm{H}$ & 0,20 & Standard \\
\hline $19 \mathrm{H}$ & 0,20 & Standard \\
\hline $20 \mathrm{H}$ & 0,20 & Standard \\
\hline $21 \mathrm{H}$ & 0,20 & Standard \\
\hline $22 \mathrm{H}$ & 0,20 & Standard \\
\hline $23 \mathrm{H}$ & 0,20 & Standard \\
\hline $24 \mathrm{H}$ & 0,20 & Standard \\
\hline $25 \mathrm{H}$ & 0,20 & Standard \\
\hline $26 \mathrm{H}$ & 0,20 & Standard \\
\hline $27 \mathrm{H}$ & 0,20 & Standard \\
\hline $28 \mathrm{H}$ & 0,20 & Standard \\
\hline $29 \mathrm{H}$ & 0,20 & Standard \\
\hline $30 x$ & No, no sample & Standard \\
\hline $31 x$ & 0,20 & Standard \\
\hline $32 x$ & No, no sample & Standard \\
\hline $33 x$ & 0,20 & Standard \\
\hline $34 \mathrm{X}$ & 0,20 & Standard \\
\hline $35 x$ & 0,20 & Standard \\
\hline $36 \mathrm{X}$ & 0,20 & Standard \\
\hline \multicolumn{3}{|c|}{ 340-U1399B- } \\
\hline $1 \mathrm{H}$ & 0,20 & Nonmagnetic \\
\hline $2 \mathrm{H}$ & 0,20 & Nonmagnetic \\
\hline $3 \mathrm{H}$ & 0,20 & Nonmagnetic \\
\hline $4 \mathrm{H}$ & 0,20 & Nonmagnetic \\
\hline $5 \mathrm{H}$ & 0,20 & Nonmagnetic \\
\hline $6 \mathrm{H}$ & 0,20 & Nonmagnetic \\
\hline $7 \mathrm{H}$ & 0,20 & Nonmagnetic \\
\hline $8 \mathrm{H}$ & 0,20 & Nonmagnetic \\
\hline $9 \mathrm{H}$ & 0,20 & Nonmagnetic \\
\hline $10 \mathrm{H}$ & 0,20 & Nonmagnetic \\
\hline $11 \mathrm{H}$ & 0,20 & Nonmagnetic \\
\hline $12 \mathrm{H}$ & 0,20 & Nonmagnetic \\
\hline $13 \mathrm{H}$ & 0,20 & Nonmagnetic \\
\hline $14 \mathrm{H}$ & 0,20 & Nonmagnetic \\
\hline $15 \mathrm{H}$ & 0,20 & Standard \\
\hline $16 \mathrm{H}$ & 0,20 & Standard \\
\hline $17 \mathrm{H}$ & 0,20 & Standard \\
\hline $18 \mathrm{H}$ & 0,20 & Standard \\
\hline $19 \mathrm{H}$ & 0,20 & Standard \\
\hline 201 & No, no sample & Standard \\
\hline $21 \mathrm{H}$ & 0,20 & Standard \\
\hline $22 \mathrm{H}$ & 0,20 & Standard \\
\hline $23 \mathrm{H}$ & 0,20 & Standard \\
\hline $24 \mathrm{H}$ & 0,20 & Standard \\
\hline $25 \mathrm{H}$ & 0,20 & Standard \\
\hline $26 \mathrm{H}$ & 0,20 & Standard \\
\hline $27 \mathrm{H}$ & 0,20 & Standard \\
\hline
\end{tabular}

$\mathrm{APC}=$ advanced piston corer 
Table T6. Traveltimes from vertical seismic profile (VSP), Hole U1399C.

\begin{tabular}{|c|c|c|c|c|c|}
\hline $\begin{array}{l}\text { Depth* } \\
\text { (mbsf) }\end{array}$ & $\begin{array}{l}\text { Depth } \\
\text { (mbsl) }\end{array}$ & $\begin{array}{c}\text { One-way } \\
\text { traveltime } \\
\text { (s) }\end{array}$ & $\begin{array}{c}\text { One-way } \\
\text { traveltime } \\
\text { corrected }^{\dagger} \\
\text { (s) }\end{array}$ & $\begin{array}{l}\text { Two-way } \\
\text { traveltime } \\
\text { (s) }\end{array}$ & $\begin{array}{l}\text { Two-way } \\
\text { traveltime } \\
\text { below } \\
\text { seafloor } \\
\text { (s) }\end{array}$ \\
\hline 99.1 & 3009.1 & 1.991 & 1.997 & 3.993 & 0.128 \\
\hline 108.9 & 3018.9 & 1.997 & 2.003 & 4.006 & 0.141 \\
\hline 124.4 & 3034.4 & 2.006 & 2.012 & 4.023 & 0.158 \\
\hline 134.9 & 3044.9 & 2.012 & 2.017 & 4.035 & 0.170 \\
\hline 160.1 & 3070.1 & 2.026 & 2.032 & 4.064 & 0.199 \\
\hline 184.1 & 3094.1 & 2.039 & 2.045 & 4.090 & 0.225 \\
\hline 210.1 & 3120.1 & 2.054 & 2.060 & 4.120 & 0.255 \\
\hline 237 & 3147 & 2.066 & 2.072 & 4.144 & 0.279 \\
\hline
\end{tabular}

${ }^{*}=$ two-way traveltime through water column $(2898.7 \mathrm{mbsl})=3.865 . \dagger=$ correction to be added to one-way traveltime $=0.00573$. 